\title{
New age constraints for early Paleogene strata of central Patagonia, Argentina: Implications for the timing of South American Land Mammal Ages
}

\author{
J. Marcelo Krause ${ }^{1,2, \dagger}$, William C. Clyde ${ }^{3}$, Mauricio Ibañez-Mejía ${ }^{4,5}$, Mark D. Schmitz ${ }^{6}$, Timothy Barnum ${ }^{3}$, \\ Eduardo S. Bellosi ${ }^{7}$, and Peter Wilf ${ }^{8}$ \\ ${ }^{1}$ CONICET-Museo Paleontológico Egidio Feruglio, Avenida Fontana 140, 9100, Trelew, Argentina \\ ${ }^{2}$ Departamento de Geología, Universidad Nacional de la Patagonia San Juan Bosco, Ruta Provincial 1 s/n, 9000, Comodoro \\ Rivadavia, Chubut, Argentina \\ ${ }^{3}$ Department of Earth Sciences, University of New Hampshire, 56 College Road, Durham, New Hampshire 03824, USA \\ ${ }^{4}$ Department of Earth, Atmospheric and Planetary Sciences, Massachusetts Institute of Technology, Cambridge, Massachusetts \\ 02139, USA \\ ${ }^{5}$ Department of Earth and Environmental Sciences, University of Rochester, Rochester, New York 14627, USA \\ ${ }^{6}$ Department of Geosciences, Boise State University, 1910 University Drive, Boise, Idaho 83725, USA \\ ${ }^{7}$ CONICET-Museo Argentino de Ciencias Naturales, Ángel Gallardo 470, 1405 Buenos Aires, Argentina \\ ${ }^{8}$ Department of Geosciences, Pennsylvania State University, University Park, Pennsylvania 16802, USA
}

\section{ABSTRACT}

The Río Chico Group in the San Jorge Basin of central Patagonia (Argentina) preserves some of South America's most significant Paleogene records of biotic and climatic change. Three of its constituent formations, the Peñas Coloradas, Las Flores, and KoluelKaike, host vertebrate faunas referred to the “Carodnia faunal zone," the Itaboraian South American Land Mammal Age (SALMA), and the Riochican SALMA. However, the precise absolute ages of these units, and thus their associated faunas and paleoclimate records, are poorly resolved. Herein, we report new paleomagnetic and geochronologic results from these formations in south-central Chubut Province, Argentina. U-Pb dating of four volcanic ashes, using both laser ablationmulticollector-inductively coupled plasmamass spectrometry and high-resolution chemical abrasion-isotope dilution-thermal ionization mass spectrometry, indicates ages of igneous crystallization of $\mathbf{5 1 . 4 0 3} \pm \mathbf{0 . 0 3 7}$ (0.045) [0.071] Ma for a level within the middle Las Flores Formation and $46.714 \pm$ 0.012 (0.026) [0.057] Ma, 44.579 \pm 0.013 $(0.026)[0.054] \mathrm{Ma}$, and $42.856 \pm 0.017(0.027)$ [0.054] Ma for levels in the lower, middle, and upper Koluel-Kaike Formation, respectively. Combining these with previous isotopic ages

†mkrause@mef.org.ar in our new magnetostratigraphic framework, we correlate the Peñas Coloradas Formation to chrons C27n-26r (ca. 62.5 to ca. 61.6 Ma; late Danian) and the section from the middle Las Flores to the uppermost Koluel-Kaike to chrons C23n to C19r (ca. 51.4-42.2 Ma; mid Ypresian-late Lutetian). We combine these data with other recently published chronostratigraphic results from Paleogene units in Patagonia to better constrain the ages of noteworthy Paleogene plant and mammal fossil sites in Patagonia and to develop a revised temporal calibration of the Las Flores, Vacan, and "Sapoan" faunas.

\section{INTRODUCTION}

Paleogene continental sequences from the San Jorge Basin, central Patagonia, Argentina, are globally significant due to their extraordinary preservation of South American fossil faunas (e.g., Simpson, 1935a, 1935b, 1948; Cifelli, 1985; Pascual and Ortiz-Jaureguizar, 1990; Bonaparte et al., 1993; Bond et al., 1995; Flynn and Swisher, 1995; Ortiz-Jaureguizar and Cladera, 2006; Gelfo et al., 2009; Madden et al., 2010; Woodburne et al., 2014a, 2014b) and floras (Berry, 1937; Romero, 1968; Archangelsky, 1973, 1976; Petriella and Archangelsky, 1975; Archangelsky and Zamaloa, 1986; Zamaloa and Andreis, 1995; Brea et al., 2005, 2007, 2008, 2011; Iglesias et al., 2007; Zucol et al., 2010). These sequences also provide records of regional biotic responses to global climatic events (e.g., Raigemborn et al., 2009, 2014; Bellosi and González, 2010; Krause et al., 2010; Dunn et al., 2015; Kohn et al., 2015; Selkin et al., 2015).

Currently, the chronostratigraphy for central Patagonia is well constrained for both early Paleocene (Clyde et al., 2014; Comer et al., 2015) and middle-late Paleogene (Ré et al., 2010a, 2010b; Dunn et al., 2013) sequences. However, the middle Paleocene-middle Eocene interval, encompassing the Las Flores and Koluel-Kaike Formations, is still poorly resolved (see also Woodburne et al., 2014b). Prior age constraints on these units came mostly from the underlying and overlying formations. Recent magnetostratigraphic and geochronological results from the underlying Salamanca-Peñas Coloradas sequences from the Sarmiento area constrain the age of the Salamanca Formation to ca. 65.7-63.5 Ma (early-middle Danian; chrons C29n and C28n, where the time scale of Gradstein et al. [2012] is used throughout this paper) and the Peñas Coloradas Formation to ca. 62.561.6 Ma (latest Danian; Chrons C27n-bottom C26r; Clyde et al., 2014; Comer et al., 2015).

The base of the Sarmiento Formation, which overlies the Koluel-Kaike Formation, is well constrained at the Gran Barranca locality (Gran Barranca Member) to 42.11-41.70 Ma (latest Lutetian, base of chron C19r) based on magnetostratigraphic and radioisotopic geochronologic data from the area (Ré et al., 2010a, 2010b; 
Dunn et al., 2013, and references cited therein). Two radioisotopic dates were also recently reported from the Las Flores Formation, which underlies the Koluel-Kaike Formation. One is a ${ }^{40} \mathrm{Ar} /{ }^{39} \mathrm{Ar}$ date of $49.512 \pm 0.019 \mathrm{Ma}$ on alkaline feldspars from a tuff in the lower portion of the formation, $20 \mathrm{~m}$ above the beds bearing the Las Flores fauna (Woodburne et al., 2014b). The other is a maximum age of sedimentation interpreted from laser ablation-inductively coupled plasma-mass spectrometry (LA-ICP-MS) U-Pb analyses of detrital zircons, which constrained the bed bearing the Las Flores fauna to be no older than ca. $47 \pm 1$ Ma (Kohn et al., 2015). These conflicting ages confound chronostratigraphic interpretation of the Las Flores Formation in this area.

In this study, we constrain the ages of the Peñas Coloradas, Las Flores, and Koluel-Kaike Formations using new radioisotopic and paleomagnetic data in the Las Flores area, which lies at the eastern extreme of the Gran Barranca in south-central Chubut Province, Patagonia, Argentina (Figs. 1A-C; Table 1). Our goals are to develop a well-defined stratigraphic framework for the San Jorge Basin, so as to better constrain the ages of some of the most significant records of Paleogene biotas in South America, and to establish a chronostratigraphic framework for improved interpretation of the important early Paleogene global climatic events recorded in South America. Improved chronostratigraphic data allow more precise correlation to other significant fossiliferous strata from Patagonia (Fig. 1C), such as those containing the Laguna del Hunco and Río Pichileufú floras (Wilf et al., 2003, 2005) and the "Sapoan" fauna (Gosses et al., 2006; Tejedor et al., 2009), and they can provide a powerful tool with which to correlate Paleogene South American Land Mammal Ages (SALMAs) represented within the Río Chico Group to land mammal biochronological zonations on other continents (e.g., North America and Asia; Woodburne, 2004; Ting et al., 2011).

\section{GEOLOGICAL SETTING}

The units representing the middle Paleocenemiddle Eocene interval in the San Jorge Basin are the Peñas Coloradas, Las Violetas, Las Flores, and Koluel-Kaike Formations (Río Chico Group sensu Raigemborn et al., 2010), and the recently defined Cañadón Vaca Member, which represents the lowermost part of the Sarmiento Formation (Bellosi and Krause, 2014; Fig. 2). We focus on the Las Flores and Koluel-Kaike Formations, which together constitute the heretofore poorly dated Middle-Upper Río Chico Group, a continental succession composed of fluvial, lacustrine, and eolian facies (Feruglio,
1949; Legarreta and Uliana, 1994; Krause et al., 2010; Raigemborn et al., 2010; Comer et al., 2015). Our study site, Las Flores, is located on the eastern margin of the San Bernardo fold belt in the San Jorge Basin, southern Argentina (Fig. 1A-1C), at the eastern extreme of the fossiliferous Gran Barranca escarpment (Fig. 1C). An additional locality, Cerro Blanco (Fig. 1C), 26 km SW of Las Flores, also was included in order to sample a volcanic tuff from the middle Las Flores Formation for isotopic dating.

Under the Las Flores Formation sits the Peñas Coloradas Formation, a fluvial unit up to $42 \mathrm{~m}$ in thickness (e.g., at Estancia la Rosa; Raigemborn et al., 2010) but typically less than $30 \mathrm{~m}$ thick (Krause, 2010). The rocks composing the Peñas Coloradas Formation are mainly medium-dark reddish, cross-bedded sandstones, related to sinuous channel filling, and subordinate mudstones and tuffs deposited in floodplain settings (e.g., Raigemborn et al., 2009, 2010; Comer et al., 2015). According to Bond et al. (1995) and Woodburne et al. (2014a, 2014b), among others, the Peñas Coloradas Formation contains vertebrate remains from the "Carodnia faunal zone," originally described by Simpson (1935a, 1935b) from Bajo Palangana and Cerro Redondo (Fig. 1B); however, this fauna is probably contained within the Las Flores Formation (see Discussion). Fossil wood has also been described from the Peñas Coloradas Formation in the area around the town of Sarmiento and at Punta Peligro along the coast (Brea et al., 2004; Brea and Zucol, 2006; Raigemborn et al., 2009).

The Las Flores Formation, a unit up to 50$52 \mathrm{~m}$ in thickness in the Gran Barranca area, is primarily composed of grayish green mudstones, with subordinate epiclastic and volcaniclastic sandstones. Toward the coast (e.g., Punta Peligro; Fig. 1B), the Las Flores Formation becomes sandier (e.g., Pico Salamanca area, close to Bajo Palangana; Fig. 1B; Krause and Piña, 2012) and thicker, with sections of more than $100 \mathrm{~m}$ thickness (Krause, 2010). Similar sandy and muddy facies in sections with thicknesses of $\sim 140 \mathrm{~m}$, including both the Peñas Coloradas and Las Flores Formations (= Riochiquense sensu Feruglio, 1949), were recorded in the Punta Peligro area by Feruglio (1949). Sedimentary facies of the Las Flores Formation have been interpreted to have been deposited in lacustrine and fluvial floodplain and channel environments (e.g., Raigemborn et al., 2009, 2010; Krause and Piña, 2012). The muddy facies contain evidence of pedogenic processes, such as mottles and rhizoliths. Fossils in the study area include vertebrate remains that are attributed to the Itaboraian SALMA (Bond et al., 1995; Goin et al., 2009; Woodburne et al., 2014b) and phytolith remains (Brea et al., 2008; Raigemborn et al., 2009).
Crocodilian coprolites were also described from the Las Flores Formation in the coastal area of Pico Salamanca, 4-5 km to the east of Bajo Palangana (Krause and Piña, 2012).

The Koluel-Kaike Formation, in the past known as the Argiles Fissilaires facies (Ameghino, 1906; McCartney, 1934) or "Tobas de Koluel-Kaike" (Feruglio, 1949), is mainly composed of pyroclastic sediments in the form of fine tuffs and bentonites (Krause et al., 2010; Raigemborn et al., 2010). Conspicuous lenticular bodies with manganese nodules are present at the base, recording shallow pond facies (Krause et al., 2010). Strongly developed reddish paleosols with a moderate to high degree of silicification are frequent throughout the section (Krause et al., 2010). At Las Flores, the KoluelKaike Formation exhibits gradational contacts with both the underlying Las Flores Formation and the overlying Sarmiento Formation (Bellosi and Madden, 2005; Krause et al., 2010, their figs. 3A and 3B).

Fossils are scarce in the Koluel-Kaike Formation, but silicified wood (Brea et al., 2009) and cicada trace fossils (Krause et al., 2008) have been recorded. Mammalian remains have never been found in the Koluel-Kaike Formation itself (e.g., Simpson, 1933a). However, siliciclastic rocks exposed along the Atlantic coast, correlated with the Koluel-Kaike Formation by Legarreta and Uliana (1994), contain mammal fossils from the Ernestokokenia faunal zone (= Riochican SALMA; Bond et al., 1995). We note that the association frequently made in the literature of the Ernestokokenia faunal zone and Riochican SALMA with the Koluel-Kaike Formation (Legarreta et al., 1990; Legarreta and Uliana, 1994; Bond et al., 1995; Woodburne et al., 2014a) is somewhat misleading because no rocks assignable to the Koluel-Kaike Formation (e.g., silicified and pedogenized tuffs) are actually found along the coast where the relevant fossil sites are located. In the coastal area where the Ernestokokenia faunal zone fossils were recovered, the upper Río Chico Group is composed of sandstones and mudstones that are lithostratigraphically assignable to the Peñas Coloradas and Las Flores Formations (Krause et al., 2010; Raigemborn et al., 2010; Krause and Piña, 2012), with the Ernestokokenia faunal zone restricted to beds from the Las Flores Formation in this area.

\section{METHODS}

\section{Sedimentary Sections and Sampling}

To stratigraphically locate the samples taken for isotope geochronology and paleomagnetic analyses, a new composite section spanning the 


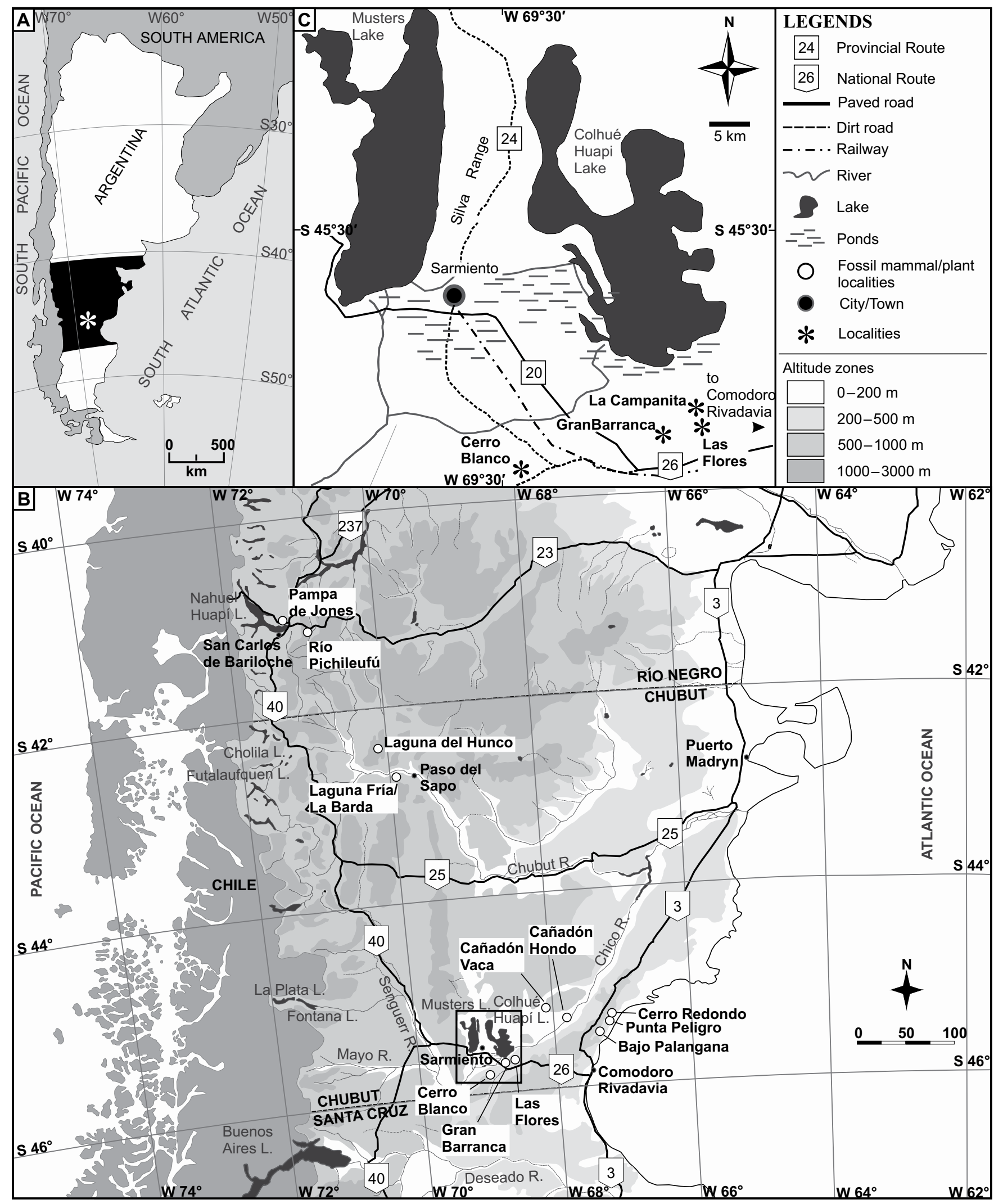

Figure 1. Maps showing location of study area and key localities referenced in text. (A) Regional setting in Argentina. The black area encompasses map in B. The white asterisk displays the position of the study area detailed in C. (B) Map of central Patagonia showing the studied localities Cerro Blanco and Las Flores (box) and other mammal and plant fossil sites in the region. (C) Detailed map of the studied localities. 
Krause et al.

TABLE 1. GEOGRAPHIC AND STRATIGRAPHIC POSITION OF ISOTOPICALLY DATED TUFF BEDS IN THIS STUDY

\begin{tabular}{|c|c|c|c|c|c|c|}
\hline Sample & Method & $\begin{array}{c}\text { GPS Lat } \\
\left({ }^{\circ} \mathrm{S}\right)\end{array}$ & $\begin{array}{c}\text { GPS Long } \\
\left({ }^{\circ} \mathrm{W}\right)\end{array}$ & Section & Formation & Stratigraphic position \\
\hline 12CB01 & U-Pb LA-MC-ICP-MS and CA-ID-TIMS & 45.8045561 & 688.9404892 & Cerro Blanco & "Middle Las Flores & P 34 m above base of LFF \\
\hline 12LFKK01 & U-Pb LA-MC-ICP-MS and CA-ID-TIMS & 45.7216162 & 68.6184061 & Las Flores & Lower Koluel-Kaike & $1 \mathrm{~m}$ above base of $\mathrm{KKF}$ \\
\hline 12LFKK03 & U-Pb LA-MC-ICP-MS and CA-ID-TIMS & 45.7223619 & 68.6189694 & Las Flores & Middle Koluel-Kaike & $23.5 \mathrm{~m}$ above base of KKF \\
\hline 12LFKK05 & U-Pb LA-MC-ICP-MS and CA-ID-TIMS & 45.7179492 & 68.6291973 & Las Flores & Upper Koluel-Kaike & $42.5 \mathrm{~m}$ above base of KKF \\
\hline
\end{tabular}

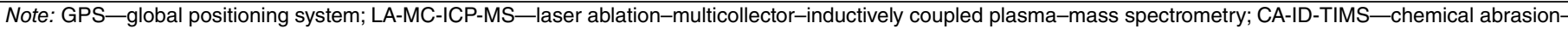

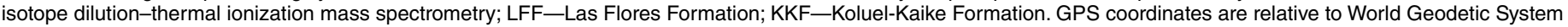
1984 (WGS84) datum.

Upper Peñas Coloradas, Las Flores, and KoluelKaike Formations was defined. The uppermost Peñas Coloradas Formation (7 $\mathrm{m}$ thick) and the base of the Las Flores Formation (lenticular bed, 5-7 $\mathrm{m}$ thick) were logged in an outcrop $\sim 1.5-2 \mathrm{~km}$ to the north of the Las Flores locality, herein referred to as La Campanita (Fig. 1C) due to its proximity to the La Campanita ranch. The rest of the Las Flores Formation $(45 \mathrm{~m}$ thick) was measured at the Las Flores locality. For the Koluel-Kaike Formation, the 57-m-thick section of Krause et al. (2010) at Las Flores was used. In total, the composite Peñas Coloradas, Las Flores, and Koluel-Kaike stratigraphic section presented here is $115 \mathrm{~m}$ thick (Fig. 3), determined using a Jacob's staff and global positioning system (GPS). Field data were represented in descriptive logs, recording lithology, mean grain size, sedimentary structures, and pedogenic features. Pedogenic horizons were identified based on macroscopic identification of changes in structure, mottling, nodules, and colors (Krause et al., 2010).

\section{Isotope Geochronology}

One sample from a tuff within the middle Las Flores Formation at Cerro Blanco (12CB01), and three samples from tuff layers within the lower, middle, and upper Koluel-Kaike Formation at Las Flores (12LFKK01, 12LFKK03, 12LFKK05; Table 1) were processed for zircon U-Pb geochronology (Figs. 1C and 3-6; Table 1; Tables DR1 and DR2 ${ }^{1}$ ). Zircons were separated using standard gravimetric and magnetic techniques, handpicked under a binocular microscope, mounted in epoxy resin, and imaged by cathodoluminescence using a secondary electron microscope (SEM-CL) prior to isotopic analysis. Zircons were first analyzed by multicollector (MC) LA-ICP-MS (Fig. 5; Table DR1 [see footnote 1]) to identify crystals that would produce dates that could be interpreted as rep-

${ }^{1}$ GSA Data Repository item 2017078, Tables DR1-DR3, Figures DR1-DR3, statement of clarification regarding the boundary between the KoluelKaike Formation and the Gran Barranca Member of the Sarmiento Formation at the Las Flores section, is available at http://www.geosociety.org/datarepository /2017 or by request to editing@ geosociety.org. resenting the eruption age of the tuffs and to resolve any possible older inherited components. Based on the LA-MC-ICP-MS spot analyses and morphological criteria, 27 grains from the four tuffs were selected for subsequent high-precision chemical abrasion-isotope dilution-thermal ionization mass spectrometry (CA-ID-TIMS) dating (Fig. 6; Table DR2 [see footnote 1]). Criteria for selection were: (1) crystals with estimated moderate $U$ concentrations, in order to reduce the likelihood of processing highly damaged grains that would be mostly corroded during the leaching step; (2) only crystals pertaining to the interpreted young clusters (see Results section for details); and (3) euhedral crystals with large aspect ratios, in order to minimize the likelihood of analyzing zircons that had undergone sedimentary transport.

\section{U-Pb LA-MC-ICP-MS Analyses}

Isotopic measurements were conducted using a Photon Machines Analyte G2 Excimer ablation system coupled to a $\mathrm{Nu}$ Instruments HRMC-ICP-MS at the Arizona LaserChron Center, University of Arizona, following the methodologies described by Cecil et al. (2011). We utilized a laser-beam diameter of $30 \mu \mathrm{m}$, firing at a repetition rate of $7 \mathrm{~Hz}$ for $15 \mathrm{~s}$ with an energy fluence of $\sim 6.2 \mathrm{~J} / \mathrm{cm}^{2}$ at the sample surface. All isotopes were simultaneously measured in static mode, with masses 238, 232, 208, 207, and 206 monitored in Faraday detectors, while 204 and 202 were measured using ion-multipliers in order to allow reliable common-Pb and $\mathrm{Hg}$ interference corrections. Interelement and mass-dependent fractionation corrections, as well as U-Th concentration estimations, were calculated by calibration with respect to an inhouse Sri Lanka zircon reference crystal with an ID-TIMS age of $563.5 \pm 3.2 \mathrm{Ma}$ (Gehrels et al., 2008). Common- $\mathrm{Pb}$ corrections were applied by using the $\mathrm{Hg}$-corrected ${ }^{204} \mathrm{~Pb}$ intensities of each individual spot, assuming an initial $\mathrm{Pb}$ composition following the model of Stacey and Kramers (1975). Systematic uncertainties for the calculated $\mathrm{U}-\mathrm{Pb}$ ratios were derived from the reproducibility of measurements made on the Sri Lanka crystal. Final ages and uncertainties were calculated using the Isoplot Excel® macro of Ludwig (2003), and quoted errors for the age calculations are presented as $\pm X[Y]$, where $X$ refers to the analytical uncertainty only, and $Y$ represents the analytical and systematic uncertainties combined. Zircons from the Palacio de los Loros (PL-1) tuff, with a CA-TIMS age of $61.984 \pm 0.041 \mathrm{Ma}$ (mean square of weighted deviates [MSWD] =0.75; Clyde et al., 2014), were analyzed as secondary reference crystals during the same analytical session. Twelve measurements conducted on four different PL-1 crystals resulted in a ${ }^{206} \mathrm{~Pb} /{ }^{238} \mathrm{U}$ weighted mean date of $62.6 \pm 1.4 \mathrm{Ma}(\mathrm{MSWD}=0.74)$, indicating that the accuracy of the LA-ICP-MS age estimates lies within the quoted uncertainties.

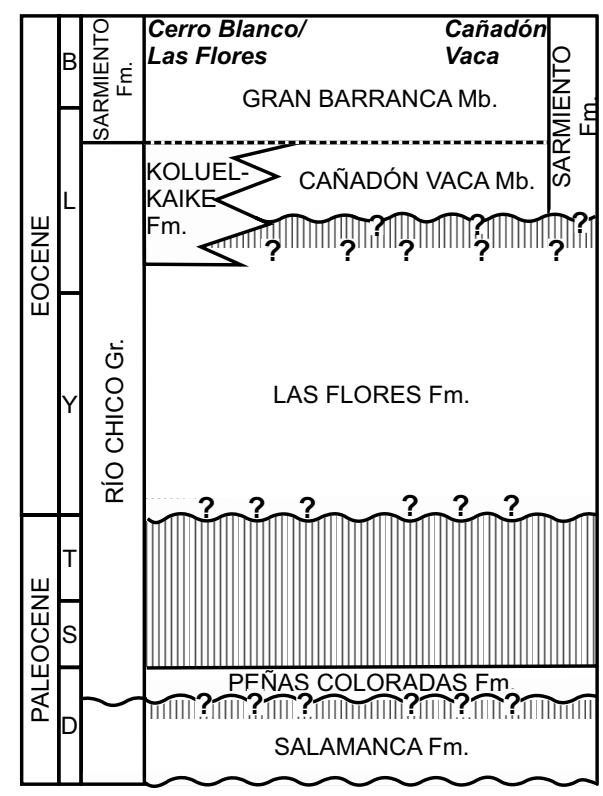

Figure 2. Updated stratigraphic chart for the study area and proposed stratigraphic relationships to Cañadón Vaca Member (lower Sarmiento Formation). Dashed lines-transitional contact; wavy lines-erosive contacts. The general scheme is a modification of that in Krause and Piña (2012). The tops of the Salamanca and Peñas Coloradas Formations are based on Clyde et al. (2014). The base of the Gran Barranca Member is based on Dunn et al. (2013). Stage abbreviations: D-Danian; S-Selandian; T-Thanetian; Y-Ypresian; L-Lutetian; B-Bartonian. 


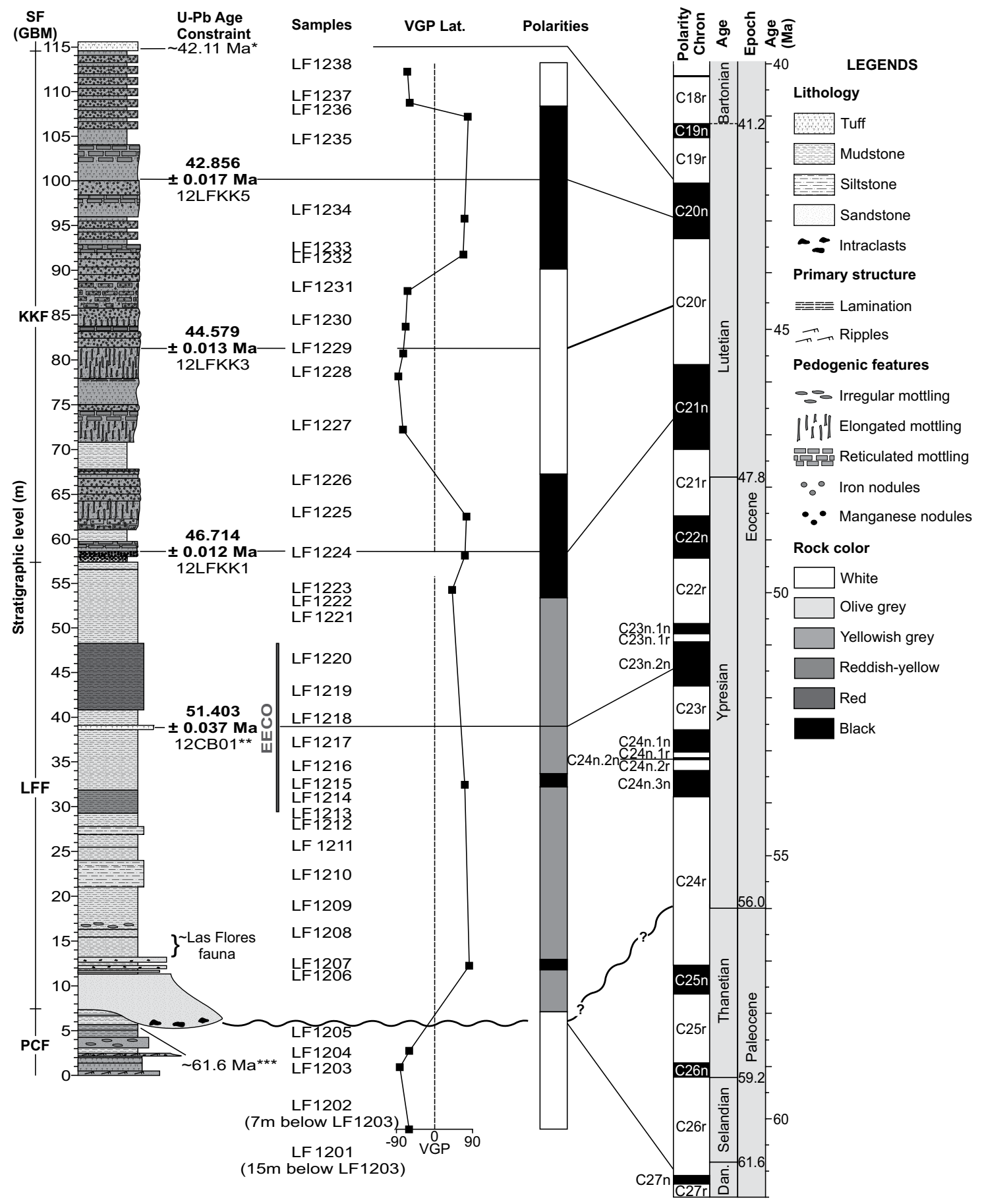

Figure 3. Chronostratigraphic information for the composite Las Flores-Koluel-Kaike section, including the Las Flores, Cerro Blanco, and La Campanita localities. (Left side) Lithostratigraphy. PCF-Peñas Coloradas Formation; LFF-Las Flores Formation; KKFKoluel-Kaike Formation; SF (GBM)-Sarmiento Formation (Gran Barranca Member). Sample numbers represent paleomagnetic sample sites (e.g., LF1201, etc.) and U/Pb dated volcanic tuffs (e.g., 12LFKK1, etc.). (Center) Magnetostratigraphy of the Las Flores section. VGP lat-virtual geomagnetic pole latitude; black is interpreted to be normal polarity, white is reverse polarity, and gray is uncertain polarity. (Right side) Geomagnetic polarity time scale (GPTS; Vandenberghe et al., 2012). Approximate stratigraphic position of the Las Flores fauna is shown based on the correlation shown in Woodburne et al. (2014b). (*) Maximum age for the Gran Barranca Member (lower Sarmiento Formation) estimated by Dunn et al. (2013), based on U/Pb dates and paleomagnetic correlation. This age more or less agrees with the previous ${ }^{40} \mathrm{Ar} /{ }^{39} \mathrm{Ar}$ mean date of $41.7 \pm 0.38 \mathrm{Ma}$ (VRS tuff sample) provided by Ré et al. (2010a). (**) Stratigraphic position of the geochronologic sample 12CB01 within the Las Flores section, after correlation of the orange-reddish mudstones. (***) Minimum age for the Peñas Coloradas Formation, determined by Clyde et al. (2014) based on U/Pb dates and paleomagnetic correlation. For additional geochronologic and paleomagnetostratigraphic data, see Tables DR1-DR3 (see text footnote 1). 

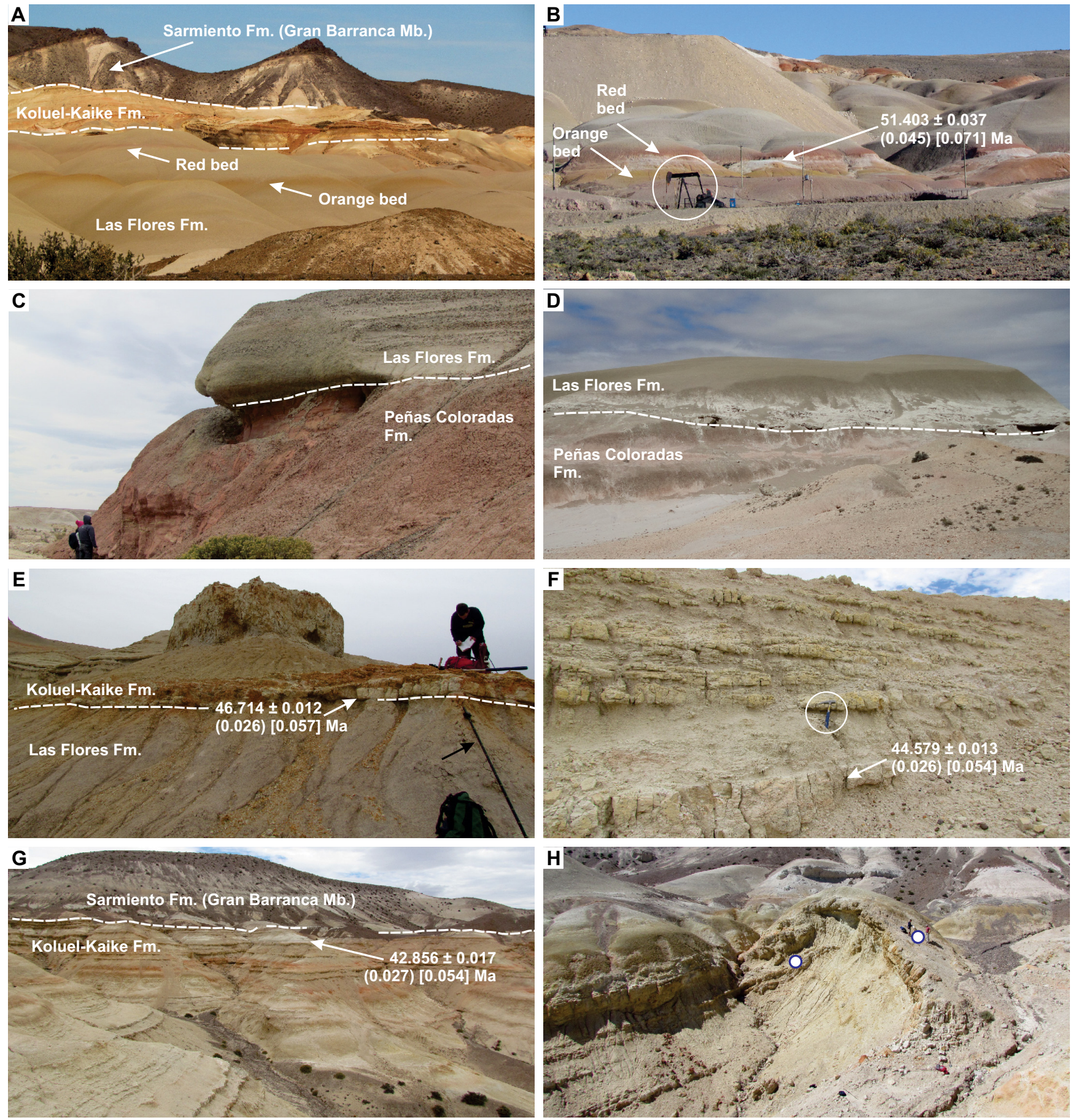

Figure 4. Selected outcrops. (A) Las Flores and Koluel-Kaike Formations at the west Las Flores locality. Note prominent orange and red marker beds within the generally homogeneous, greenish Las Flores exposures. Thickness between orange and red beds is 9 m. (B) The Las Flores Formation at Cerro Blanco (south-facing), where the orange and red marker beds (in background) bracket the white tuff (sample 12CB01). The pumpjack (encircled) height is $\sim 10 \mathrm{~m}$ (see also Fig. 6A; Table 1; Table DR2 [see text footnote 1]). (C) Basal channel scour of the Las Flores Formation at La Campanita (east-facing). The contact with the reddish sandstone of the underlying Peñas Coloradas Formation is clearly unconformable and erosive. People (at bottom left) are $\sim 1.70 \mathrm{~m}$ height. (D) The Las Flores Formation in erosive contact with the underlying Peñas Coloradas Formation at Cañadón Vaca area (exposure facing to southeast). The depth of the scour at base of the white bed is $1.6 \mathrm{~m}$. (E-G) Sample localities in the Koluel-Kaike Formation for tuff samples 12LFKK01 (E), 12LFKK03 (F), and 12LFKK05 (G) (see also Figs. 6B-6D; Table 1). The black arrow in E indicates a Jacob's staff (1.6 $\mathrm{m}$ height). The circle in $\mathrm{F}$ encloses a hammer $(0.33 \mathrm{~m}$ long). The sampled, white bed in $\mathrm{G}$ is $0.9 \mathrm{~m}$ thick. (H) Small fold in Koluel-Kaike Formation (south-facing) where paleomagnetic fold test was applied. Dots display sites for the paleomagnetic fold test (see also Fig. DR1 [see text footnote 1]). The person standing to the right of the right dot is $1.8 \mathrm{~m}$ height. 

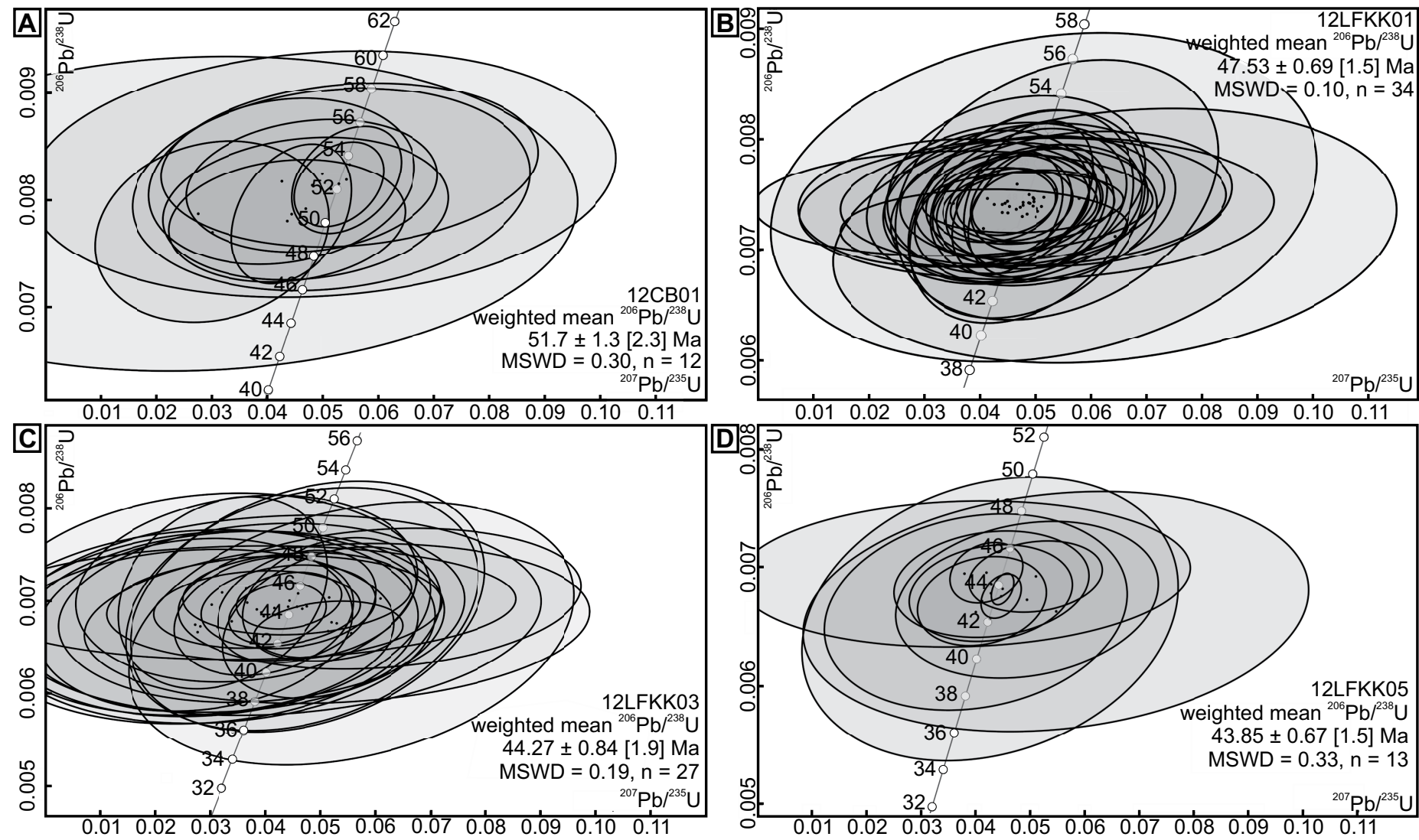

Figure 5. U-Pb concordia diagrams from laser ablation-multicollector-inductively coupled plasma-mass spectrometry (LA-MC-ICP-MS) analytical results for the tuffs analyzed in the Las Flores and Koluel-Kaike Formations: (A) middle Las Flores Formation; (B) lower KoluelKaike Formation; (C) middle Koluel-Kaike Formation; (D) upper Koluel-Kaike Formation. See text, Table 1, and Table DR1 for details (see text footnote 1). MSWD—mean square of weighted deviates.

\section{U-Pb CA-ID-TIMS Analyses}

The 27 selected zircons were subjected to a modified version of the chemical abrasion method of Mattinson (2005). Zircon crystals selected on the basis of LA-MC-ICP-MS spot analyses were plucked from the epoxy mount, annealed in quartz crucibles in a muffle furnace at $900{ }^{\circ} \mathrm{C}$ for $60 \mathrm{~h}$, chemically abraded using a single abrasion step in concentrated HF at $180{ }^{\circ} \mathrm{C}$ for $12 \mathrm{~h}$, and processed for CA-IDTIMS using the EARTHTIME ${ }^{205} \mathrm{~Pb}^{233} \mathrm{U}-{ }^{235} \mathrm{U}$ mixed tracer (Condon et al., 2015). Further details of ID-TIMS analysis have been described by Davydov et al. (2010) and Schmitz and Davydov (2012).

$\mathrm{U}-\mathrm{Pb}$ dates and uncertainties were calculated using the algorithms of Schmitz and Schoene (2007), and the U decay constants of Jaffey et al. (1971). The ${ }^{206} \mathrm{~Pb} /{ }^{238} \mathrm{U}$ ratios and dates were corrected for initial ${ }^{230} \mathrm{Th}$ disequilibrium using a $\mathrm{Th} / \mathrm{U}_{\text {[magma] }}$ of $3 \% \pm 10 \%$. All common $\mathrm{Pb}$ in analyses was attributed to laboratory blank and subtracted based on the measured laboratory $\mathrm{Pb}$ isotopic composition and associated uncertainty. U blanks were $<0.1 \mathrm{pg}$.
The weighted mean radioisotopic date error includes analytical uncertainties based on counting statistics, mass fractionation correction, spike and blank subtraction, and ${ }^{230} \mathrm{Th}$ disequilibrium correction, and it is appropriate to compare to other ${ }^{206} \mathrm{~Pb} /{ }^{238} \mathrm{U}$ dates obtained with spikes cross-calibrated with the EARTHTIME gravimetric standards. When comparing our dates with those derived from other decay schemes (e.g. ${ }^{40} \mathrm{Ar} /{ }^{39} \mathrm{Ar},{ }^{187} \mathrm{Re}-{ }^{187} \mathrm{Os}$ ), the uncertainties in tracer calibration $( \pm<0.03 \%$; McLean et al., 2015) and $U$ decay constants $( \pm 0.108 \%$; Jaffey et al., 1971) should be added to the internal error in quadrature. Quoted errors for individual analyses are thus of the form $\pm X(Y)$ $[Z]$, where $X$ is solely analytical uncertainty, $Y$ is the combined analytical and tracer uncertainty, and $Z$ is the combined analytical, tracer, and ${ }^{238} \mathrm{U}$ decay constant uncertainty.

\section{Paleomagnetism}

In total, 171 paleomagnetic samples from 40 sites within the 115 -m-thick composite section were collected (Fig. 3; Table DR3 [see footnote 1]). Paleomagnetic samples were collected at $\sim 5 \mathrm{~m}$ intervals, although the spacing varied based on the availability of appropriate fine-grained facies. Oriented hand samples were taken from the Peñas Coloradas and Las Flores Formations, whereas a rock drill was used for the majority of sampling within the KoluelKaike Formation. All paleomagnetic and rock magnetic measurements were performed at the University of New Hampshire Paleomagnetism Laboratory. Magnetic susceptibility measurements were conducted using a Bartington MS2 Susceptibility System and MULTISUS software for data collection. Samples were mass normalized and measured at both a low-frequency setting of $0.465 \mathrm{kHz}$ and high-frequency setting of $4.65 \mathrm{kHz}$. Three measurements were taken for each sample and averaged for a final value, with three samples typically measured from each site. Isothermal remanent magnetization (IRM) experiments were performed on a subset of representative samples that included two samples from the Las Flores Formation and two from the Koluel-Kaike Formation. Acquisition of IRM was achieved using an ASC IM10 impulse mag- 

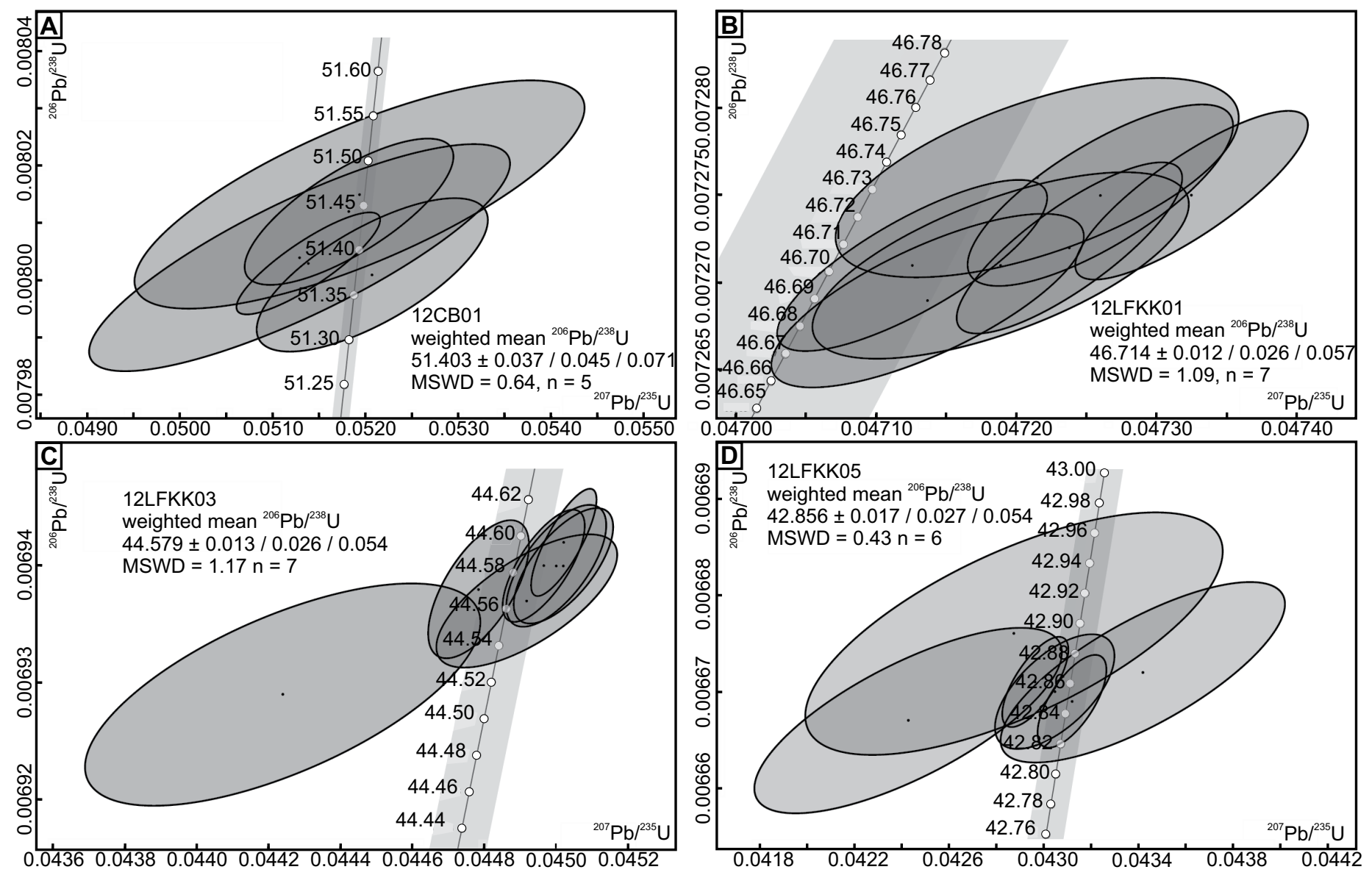

Figure 6. U-Pb concordia diagrams from chemical abrasion-isotope dilution-thermal ionization mass spectrometry (CA-ID-TIMS) analytical results for the tuffs analyzed in the Las Flores and Koluel-Kaike Formations: (A) middle Las Flores Formation; (B) lower Koluel-Kaike Formation; (C) middle Koluel-Kaike Formation; (D) upper Koluel-Kaike Formation. See text, Table 1, and Table DR2 for details (see text footnote 1). MSWD-mean square of weighted deviates.

net with a peak field strength of $1.1 \mathrm{~T}$ followed by thermal demagnetization of three orthogonal IRMs (Lowrie, 1990) of $1.1 \mathrm{~T}$ ( $x$-axis), $0.4 \mathrm{~T}$ ( $y$-axis), and 0.12 (z-axis) by an ASC Model TD48-SC thermal demagnetizer. Measurements of IRM intensities during progressive demagnetization were made using a HSM 2 SQUIDbased spinner magnetometer.

Characteristic remanent magnetization (ChRM) directions were determined for three samples from each site. Remanent directions were measured using a 2G 755 4K Superconducting Rock Magnetometer with the CryoMag software package for data collection (Wack, 2010). Step-wise thermal demagnetization was performed on samples from both the Peñas Coloradas and Koluel-Kaike Formations using an ASC Model TD48-SC thermal demagnetizer. Alternating field (AF) demagnetization using a MOLSPIN AF demagnetizer was chosen for samples from the Las Flores Formation. PuffinPlot was used for applying principal component analysis to calculate remanent directions of samples and for calculation of Fisher site statistics (Lurcock and Wilson, 2012). The Watson (1956) test for randomness was used to identify sites with significant clustering of sample directions. Site mean ChRM directions and virtual geomagnetic poles (VGPs) were then calculated and used for polarity interpretations. Although the strata in the field area are subhorizontal, we sampled one localized fold to perform a fold test (sites LF12039 and LF12040; Fig. 4H; Fig. DR1 [see footnote 1]). The reversal test of Tauxe et al. (2016) was also applied to determine whether the ChRM site mean directions were antipodal.

\section{Chronological Correlation Among Paleogene Beds in Argentine Patagonia}

The new magnetostratigraphic and geochronological data reported here were combined with previous published data to correlate the Río Chico Group sequences at Las Flores to the Geomagnetic Polarity Time Scale (GPTS;
Gradstein et al., 2012). The temporal correlation among fossiliferous units from the Paleogene of Argentine Patagonia was established on the basis of the $\mathrm{U}-\mathrm{Pb}$ dates reported here and radioisotopic dates previously reported from the Salamanca and Peñas Coloradas Formations (Clyde et al., 2014), the lower Sarmiento Formation (Ré et al., 2010a, 2010b; Strömberg et al., 2013; Dunn et al., 2013, 2015), and the La Huitrera Formation (Mazzoni et al., 1991; Wilf et al., 2003, 2005, 2010; Gosses et al., 2006). We also considered the La Meseta Formation (Cucullaea I Allomember) from the Antarctic Peninsula (Montes et al., 2012, 2013), which includes faunas considered to be similar to the "Sapoan" fauna (e.g., Tejedor et al., 2009; Goin et al., 2012; Woodburne et al., 2014a). Regarding the geochronologic data from the La Huitrera Formation, it is important to note that the age for the "Sapoan" fauna cited by Tejedor et al. (2009) was based on preliminary data reported by Gosses et al. (2006) and Gosses (2006) that have not been subsequently vetted or revised. 
For the geochronological data from the Laguna del Hunco, Río Pichileufú, and Pampa de Jones sites, we used ${ }^{40} \mathrm{Ar} /{ }^{39} \mathrm{Ar}$ dates that are slightly older than those reported by Wilf et al. (2003, $2005,2010)$ because they were recalculated using updated geochronologic standards by M. Smith (2011, personal commun. to P. Wilf) as detailed by Wilf (2012). Such recalculation relative to the astrochronologically calibrated, revised 28.01 Ma age for the Fish Canyon tuff sanidine provides a more accurate date, reducing the method's absolute uncertainty to $0.25 \%$, i.e., noticeably smaller than the uncertainty of $\sim 2.5 \%$ attached to previous astronomical calibration methods (Kuiper et al., 2008).

\section{RESULTS}

\section{Sedimentology of the Las Flores Formation}

A typical badland landscape characterizes the exposures of the Las Flores Formation in the Las Flores and Cerro Blanco areas (Figs. $4 \mathrm{~A}-4 \mathrm{~B})$. The monotony of the greenish badlands is interrupted in the middle-upper section by two orange- and reddish-colored marker beds that are easily recognizable and regionally distributed (Figs. 4A-4B). The Las Flores tuff sample 12CB01 is white in color and was collected in the Cerro Blanco area between the orange and red beds, $18 \mathrm{~m}$ below the contact with the Koluel-Kaike Formation (Figs. 3 and 4B). At the Las Flores Formation type locality, this white tuff is absent, but the orange-reddish mudstones are present, allowing lithostratigraphic correlation of tuff sample 12CB01 to the Las Flores Formation type section. The muddy facies exposed as badlands constitute the middle-upper section of the Las Flores Formation at Las Flores and Cerro Blanco, but more sandy facies are recognized to the east, for instance, in the coastal area (e.g., Krause and Piña, 2012). Las Flores Formation facies correspond to distal floodplain deposits (massive mudstones) and sinuous channels (sandstone, tuffs, and tuffaceous sandstones; e.g., Krause and Piña, 2012). At the Las Flores locality, the muddy facies from the middle-upper Las Flores Formation contain frequent rhizoliths, pedogenic blocky structure, and well-developed slickensides, indicating subaerial exposure and pedogenesis. The base of the Las Flores Formation is not exposed at Las Flores, but it can be recognized at La Campanita (Fig. 1C). There, the contact is undoubtedly unconformable, with the coarse conglomerate and grayish coarse sandstones of the Las Flores Formation lying on top of reddish sandstones of the Peñas Coloradas Formation (Fig. 4C) along a clearly erosive surface, in agreement with previous interpretations (Raigemborn et al., 2010). Considering this basal channel, the thickness of the composite section of the Las Flores Formation in the Las Flores area is greater than previous estimates, reaching up to $52 \mathrm{~m}$.

Additional observations from other localities within the San Jorge Basin confirm the discordant, erosive nature of the contact between the Peñas Coloradas and Las Flores Formations. For instance, the type of unconformable contact described at La Campanita is also present, at outcrop scale, at Cañadón Vaca (Fig. 4D) and the coastal area (e.g., Punta Peligro), frequently along an irregular surface that has up to 2-3 m in relief. In the coastal area, the Las Flores Formation overlies both the Peñas Coloradas and the Las Violetas Formation, depending on the site of observation and as a consequence of the lateral stratigraphic relationship of the latter two formations (e.g., Raigemborn et al., 2010; Krause and Piña, 2012). At Las Violetas, where the Peñas Coloradas is absent, the lower, erosive contact of the Las Flores Formation is on the Las Violetas Formation. A few kilometers to the west-southwest of Las Violetas, the Las Flores Formation unconformably overlies the Peñas Coloradas Formation. This widespread unconformity was previously suggested by Raigemborn et al. (2010) based on outcrop information, and earlier by Legarreta and Uliana (1994) based on subsurface data, and our observations provide further confirmation.

\section{Geochronology}

\section{U-Pb LA-MC-ICP-MS Analyses}

Results from 122 zircons that were analyzed from four tuff samples of the Las Flores and Koluel-Kaike Formations using the LA-MCICP-MS method are shown in Figure 5, Table 1, and Table DR1 (see footnote 1). Although some of the samples included distinctly older zircons of variable ages, indicative of some degree of sedimentary reworking ("inherited"), all tuffs yielded younger groups of statistically indistinguishable dates that we interpret as representing common times of eruption. Calculated ages for these samples constrain the middle Las Flores to Koluel-Kaike succession to an age range of early to middle Eocene (Figs. 3 and 5; Table 1). From the 122 new LA-MC-ICP-MS dates referenced here, 36 were identified as inherited (Table DR1 [see footnote 1]). Because the vast majority of the crystals that were interpreted to be inherited yielded Paleocene or older dates, their distinction from the younger (Eocene) clusters used for age estimation was unambiguous.

The tuff sample from the middle Las Flores Formation at Cerro Blanco (Figs. 3 and 4B; Table 1) yielded an age of $51.7 \pm 1.3[2.3] \mathrm{Ma}$ $(n=12 ;$ MSWD $=0.30$; Fig. 5A; Table DR1 [see footnote 1]). The age of igneous crystallization for the tuff from the lower Koluel-Kaike Formation (Fig. 3; Table 1) was estimated to be $47.53 \pm 0.69[1.5] \mathrm{Ma}(n=34 ; \mathrm{MSWD}=0.10$; Fig. 5B; Table DR1 [see footnote 1]). The tuff from the middle Koluel-Kaike Formation (Figs. 3 and 4F; Table 1) yielded an age of $44.27 \pm 0.84$ [1.9] Ma $(n=27$; MSWD =0.19; Fig. 5C; Table DR1 [see footnote 1]), while the tuff from the upper Koluel-Kaike Formation (Fig. 3; Table 1) was estimated to be $43.85 \pm 0.67$ [1.5] Ma ( $n=$ 13; MSWD $=0.33$; Fig. 5D; Table DR1 [see footnote 1]). All of these ages were later refined by high-precision CA-ID-TIMS analyses in selected crystals, as discussed next.

\section{U-Pb CA-ID-TIMS Analyses}

Although some previously undetected inherited components beyond the resolution of LAMC-ICP-MS were also discovered from the CA-ID-TIMS data (Table DR2 [see footnote 1]), all our samples yielded tight clusters of at least five concordant and statistically equivalent dates that can be used to place reliable constraints on the age of the Río Chico Group. Based on these equivalent clusters, we report weighted mean ages of these youngest grain populations that estimate the timing of igneous zircon crystallization for the four dated samples; these crystallization ages are in turn interpreted as closely approximating the eruption and depositional age of these tuffs (e.g., Bowring and Schmitz, 2003).

Middle Las Flores Formation. Of the seven zircon crystals analyzed from the white tuff between the orange and red beds in Cerro Blanco (sample 12CB01; Figs. 3 and 4B; Table 1), one grain contained an anomalous amount of common $\mathrm{Pb}$ (likely sourced from glass or mineral inclusions), and one grain yielded a resolvably older date (interpreted as detrital or having a contribution from an older core); these two analyses were not considered further. The remaining five crystals yielded a weighted mean ${ }^{206} \mathrm{~Pb} /{ }^{238} \mathrm{U}$ date of $51.403 \pm 0.037(0.045)[0.071] \mathrm{Ma}(n=5$; MSWD = 0.64; Fig. 6A; Table DR2 [see footnote 1]), which constrains the deposition of the upper Las Flores Formation to the Ypresian (Fig. 3; Table DR3 [see footnote 1]).

Lower Koluel-Kaike Formation. All seven zircon crystals from sample 12LFKK01 (Figs. 3 and 4E; Table 1) yielded equivalent $\mathrm{U}-\mathrm{Pb}$ isotope ratios, resulting in a weighted mean ${ }^{206} \mathrm{~Pb} /{ }^{238} \mathrm{U}$ date of $46.714 \pm 0.012(0.026)$ [0.057] Ma $(n=7$; MSWD = 1.09; Fig. 6B; Table DR2 [see footnote 1]).

Middle Koluel-Kaike Formation. All seven zircon crystals from sample 12LFKK03 (Figs. 3 and 4F; Table 1) were concordant and equiva- 
lent in their $\mathrm{U}-\mathrm{Pb}$ isotope ratios and yielded a weighted mean ${ }^{206} \mathrm{~Pb} /{ }^{238} \mathrm{U}$ date of $44.579 \pm$ 0.013 (0.026) [0.054] Ma $(n=7 ; \mathrm{MSWD}=$ 1.17; Fig. 6C; Table DR2 [see footnote 1]).

Upper Koluel-Kaike Formation. Of the seven zircon crystals analyzed from sample 12LFKK05 (Figs. 3 and 4G; Table 1), one grain yielded a resolvably older date interpreted as having a contribution from cores of significantly older, xenocrystic origin. The remaining six younger dates were concordant and equivalent, yielding a weighted mean ${ }^{206} \mathrm{~Pb} / 238 \mathrm{U}$ date of $42.856 \pm 0.017$ $(0.027)[0.054] \mathrm{Ma}(n=6 ; \mathrm{MSWD}=0.43$; Fig. 6D; Table DR2 [see footnote 1]).

\section{Paleomagnetism}

Mass specific magnetic susceptibility of the paleomagnetic samples ranged between 1.3 and $38.710^{-8} \mathrm{~kg} / \mathrm{m}^{3}$. The highest susceptibilities occurred close to the base of the Las Flores Formation at site LF1206 (Table DR3 [see footnote 1]). Samples from the Peñas Coloradas Formation also showed relatively high susceptibilities, whereas the Koluel-Kaike Formation samples generally were characterized by lower susceptibilities (Table DR3 [see footnote 1]).

During IRM acquisition, samples from sites LF1211 and LF1221 of the Las Flores Formation and LF1239 from the Koluel-Kaike Formation showed a rapid increase in magnetization, with saturation occurring near $0.2 \mathrm{~T}$ (Fig. DR2A [see footnote 1]). This rapid acquisition of magnetization suggests that the magnetic mineralogy of these samples is dominated by a low-coercivity mineral such as magnetite, maghemite, or pyrrhotite. Demagnetization of these samples showed that the low-coercivity component ( $z$-axis) responsible for the majority of magnetization has an unblocking temperature near $580{ }^{\circ} \mathrm{C}$ (Figs. DR2B, DR2C, and DR2E [see footnote 1]), indicating that magnetite is the dominant carrier of magnetic remanence in these samples. Site LF1225 of the Koluel-Kaike Formation was characterized by a high-coercivity mineral; saturation was still not reached even at the maximum applied field of $1.1 \mathrm{~T}$ (Fig. DR2A [see footnote 1]), suggesting a magnetic mineralogy that includes a high-coercivity mineral such as hematite or goethite. Thermal demagnetization of this sample showed an unblocking temperature for the hard IRM fraction ( $x$-axis) of $\sim 120{ }^{\circ} \mathrm{C}$ (Fig. DR2D [see footnote $1]$ ), indicating that goethite is the dominant carrier of magnetic remanence. It is likely that the goethite is pedogenic in origin because KoluelKaike Formation paleosols display hydromorphic Fe/Mn features (Krause et al., 2010).

Paleomagnetic data for all sites that passed the Watson test for randomness are shown in Table
DR3 (see footnote 1). Of the five sites sampled from the Peñas Coloradas Formation, four passed the Watson test and showed reverse polarities (Figs. 7A-7B; Table DR3 [see footnote 1]). Within the Las Flores Formation, only four of 18 sites passed the Watson test and could be used for magnetostratigraphic correlation (Figs. 7C7E). Las Flores sites failing the Watson test (e.g., Figs. 7C and 7E) usually consisted of samples with a low-temperature, unstable demagnetization. Dual-frequency magnetic susceptibility measurements on these unstable Las Flores Formation samples were generally low (e.g., $<4)$ and do not indicate appreciable amounts of superparamagnetic grains, but demagnetization results do indicate an erratic viscous remanence. This viscous magnetization acquired by the Las Flores samples is probably due to the very finegrained nature of these facies, which are dominated by clays (smectite and kaolinite; Raigemborn et al., 2009, 2014; Krause et al., 2010). Las Flores sites that passed the Watson test all displayed normal polarity and did not show this erratic behavior (Figs. 3 and 7D).

The majority of sites within the Koluel-Kaike Formation passed the Watson test for randomness, producing a more complete magnetostratigraphic section than the Las Flores Formation (Table DR3 [see footnote 1]). During demagnetization, the majority of samples from the Koluel-Kaike Formation showed a linear decay toward the origin following the removal of a weak overprint (Figs. 7F-7H). This unit contains a normal polarity site near the base of the sequence, with a reversal occurring between sites LF1225 and LF1227 (Fig. 3). The overlying reverse polarity interval extends up to site LF1231, where it then changes to normal polarity at site LF1233. A reverse polarity interval is then identified starting at site LF1237, extending upward toward the base of the overlying Sarmiento Formation.

The reversal test was applied to ChRM site mean directions from the Koluel-Kaike Formation sites that passed the Watson test to determine if the reverse and normal polarity modes in the data set are antipodal (Tauxe et al., 2016). Results indicate that the means of the reverse and normal modes cannot be distinguished at the $95 \%$ confidence level, and thus the data pass the reversal test (Fig. DR3 [see footnote 1]). Passage of the reversal test suggests that secondary natural remanent magnetization (NRM) components have been completely removed from the Koluel-Kaike Formation samples and that the ChRM is likely to be primary.

A fold test was performed on paleomagnetic directions from two sites in the Koluel-Kaike Formation to determine if magnetization was acquired prior to deformation. Passage of the fold test requires that $\mathrm{ChRM}$ directions on different limbs of a fold become more clustered following structural corrections. The two sites positioned on the limbs of the local fold (Fig. 4H; Fig. DR1; Table DR3 [see footnote 1]) show much better clustering $(F=4.53, p<0.01)$ with the rest of the sites when converted from geographic to stratigraphic coordinates, indicating a prefolding magnetization (Fig. DR1 [see footnote 1]).

\section{DISCUSSION}

There has been considerable discussion about how the sedimentary facies and constituent fossils of the Río Chico Group relate to the global climate changes of the early Paleogene (e.g., Raigemborn et al., 2009, 2014; Krause et al., 2010; Woodburne et al., 2014a, 2014b). Of particular interest is how the Paleogene Patagonian mammal faunas temporally relate to one another (e.g., Tejedor et al., 2009; Woodburne et al., 2014a, 2014b) and how they, in turn, correlate to the long-term global warming and subsequent cooling associated with the early Eocene climate optimum (51-53 Ma; Zachos et al., 2001, 2008). The new magnetostratigraphic and geochronological data from the Las Flores-Koluel-Kaike succession reported here fill the gap of information existing in the early Eocene (Ypresian) to middle Eocene (Lutetian) interval of central Patagonia (Fig. 3), after the deposition of the Peñas Coloradas Formation (latest Danian, ca. 62.5-61.6 Ma; Clyde et al., 2014) and before the beginning of deposition of the Gran Barranca Member of the Sarmiento Formation (latest Lutetian, 42.11-41.70 Ma; Ré et al., 2010a, 2010b; Dunn et al., 2013). The new age constraints presented here for the Peñas Coloradas, Las Flores, and KoluelKaike Formations that make up the Río Chico Group are discussed next, along with our revised understanding of the ways in which each of these units and their associated faunas relates to early Paleogene global climate changes and to other Patagonian biotas (Fig. 8).

\section{Age of the Río Chico Group and Related Mammal Faunas}

\section{Peñas Coloradas Formation (Ca. 62.5-61.6 Ma)}

The Peñas Coloradas Formation is estimated to have been deposited between ca. 62.5 and ca. 61.6 Ma (chrons C27n-26r) based on previous $\mathrm{U}-\mathrm{Pb}$ and paleomagnetic data (Clyde et al., 2014) and the new magnetostratigraphic data presented here (Fig. 3). According to the schemes of Legarreta and Uliana (1994) and Bond et al. (1995), mammalian remains of the "Carodnia faunal zone," originally recorded 

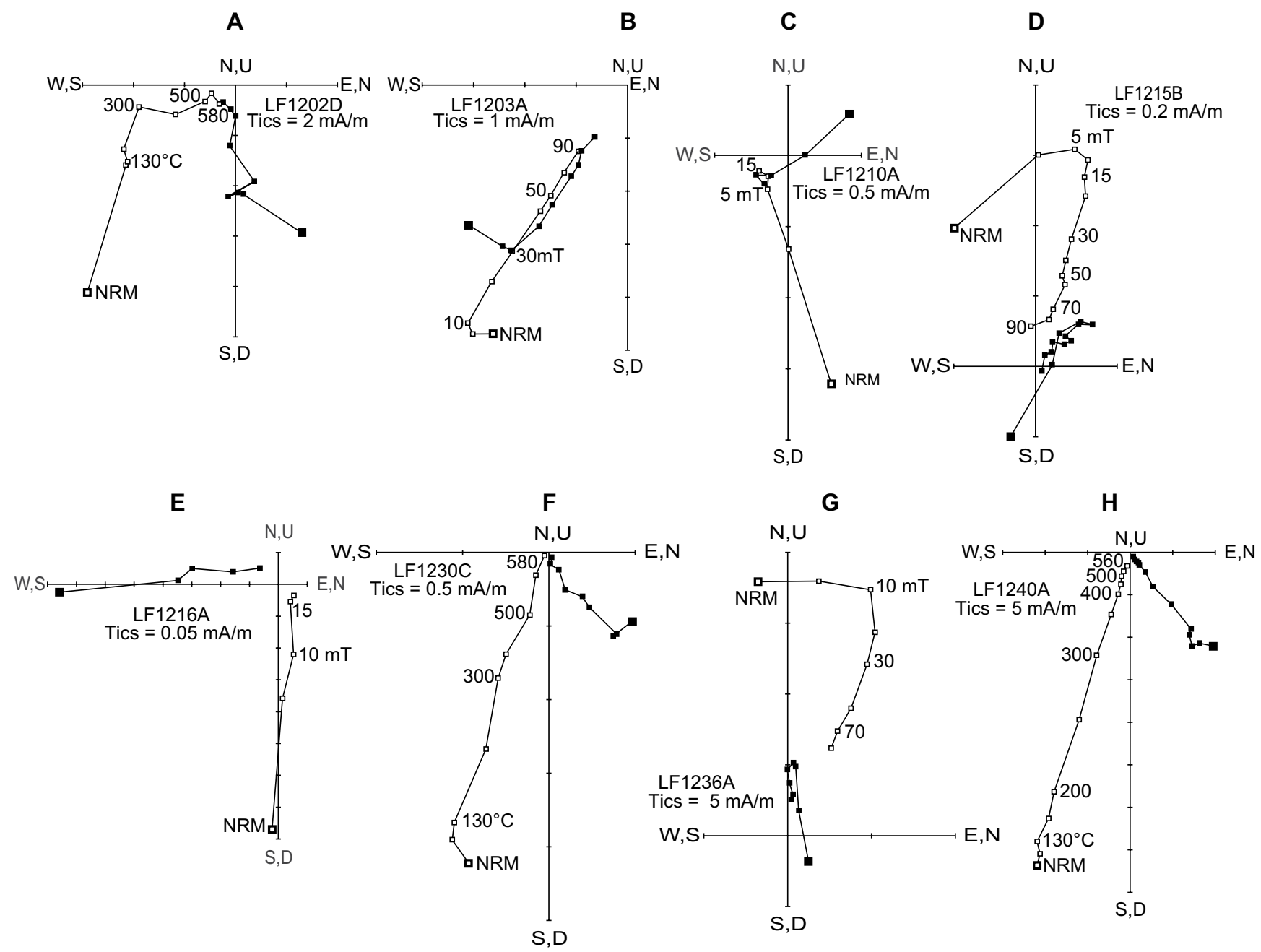

Figure 7. Representative paleomagnetic vector end-point diagrams from the (A, B) Peñas Coloradas Formation; (C-E) Las Flores Formation; and (F-H) Koluel-Kaike Formation. Las Flores samples LF1210A (C) and LF1216A (E) are from sites that showed unstable demagnetization results and were not included in the final magnetostratigraphic data set. NRM-natural remanent magnetization.

at several localities from the coastal area (e.g. Cerro Redondo, Bajo Palangana; Simpson, 1935a, 1935b), were considered to have come from the Peñas Coloradas Formation. Following this scheme, and based on the age estimate of 61.6 Ma provided by Clyde et al. (2014) for the top of the Peñas Coloradas Formation, Woodburne et al. (2014b) correlated the "Carodnia zone" to ca. $62 \mathrm{Ma}$. However, it is important to note that the original descriptions (e.g., Simpson, 1935b; Feruglio, 1949) of the eastern fossil localities (e.g., Bajo de la Palangana, Cerro Redondo) would place them at a stratigraphic level that is above the Peñas Coloradas Formation (Krause, 2010). For example, the "Carodnia zone" fossils in Bajo Palangana are stated to be $46 \mathrm{~m}$ above the base of the Río Chico beds (e.g., Feruglio, 1949); however, in this area, the Peñas Coloradas Formation is only $30-35$ m thick, suggesting that the "Carodnia faunal zone"
Figure 8 (on following page). Correlation scheme integrating geochronological information (Mazzoni et al., 1991; Gosses et al., 2006; Dunn et al., 2013; Montes et al., 2012, 2013; Clyde et al., 2014; this work), lithostratigraphic units constituting the Río Chico Group and the lower Sarmiento Formation (Raigemborn et al., 2010; Krause and Piña, 2012; Bellosi and Krause, 2014), Patagonian fossil plant (Wilf et al., 2003, 2005, 2010) and mammal assemblages (Cifelli, 1985; Bond et al., 1995; Tejedor et al., 2009; Goin et al., 2012; Vandenberghe et al., 2012; Reguero et al., 2013; Woodburne et al., 2014a, 2014b; Gelfo et al., 2015), and the global deep-sea oxygen isotope and paleoclimatic record (Zachos et al., 2001, 2008). South America land mammal ages (SALMAs) are indicated in capital letters. Bars indicate mammal assemblages and floras and/or biotas. NALMA-North America land mammal age; SF-Sarmiento Formation; MECO-middle Eocene climatic optimum; EECO-early Eocene climatic optimum; ETM2-Eocene thermal maximum 2; PETMPaleocene-Eocene thermal maximum (ETM1). CUC I-Cucullaea I Allomember (bearing fauna from La Meseta Formation; Montes et al., 2012; Montes, personal commun., 2015, to J.M. Krause). (*) Ages after Dunn et al. (2013). (**) Ages after Clyde et al. (2014). (***) Ages subject to stratigraphic and geochronological revision. See text for details. 


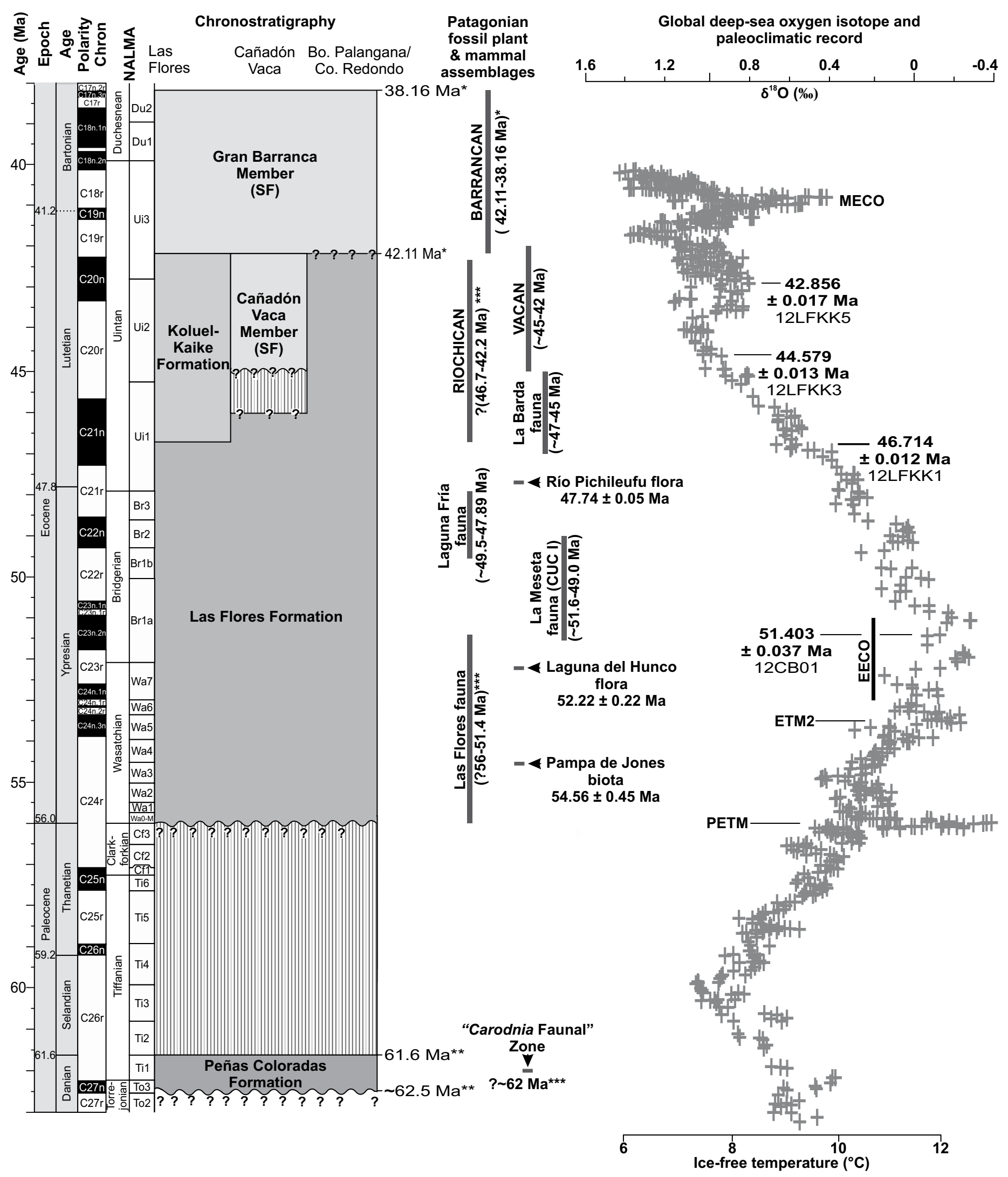

Figure 8. 
could correspond to Las Flores beds there. The precise stratigraphic position and age of the "Carodnia" assemblage need to be resolved via direct geological investigations of the sections bearing the original fossils and further paleontological sampling in well-defined sections.

\section{Las Flores Formation (?56-47 Ma)}

The geochronological and paleomagnetic study provided by Clyde et al. (2014) and reinforced by new paleomagnetic information from this study suggest that the lowest part of the Las Flores Formation corresponds to chron C26n or younger (i.e., younger than 59.2 Ma). The poor paleomagnetic behavior within the lower Las Flores Formation at the Las Flores locality reduces the geochronological resolution for this part of the section; however, both the isotopic ages provided in this study and the very stable paleomagnetic behavior within the overlying Koluel-Kaike Formation show a close match to the GPTS (Vandenberghe et al., 2012).

The tuff sample 12CB01 from the middle Las Flores Formation at Cerro Blanco (Figs. 1B, 3, $4 \mathrm{~B}$, and 8 ), located between the orange and red marker beds, can be correlated with the interval close to site LF1215 in the Las Flores section (Fig. 3), which is normal polarity. The $\mathrm{U}-\mathrm{Pb}$ date of $51.403 \pm 0.037 \mathrm{Ma}$ for $12 \mathrm{CB} 01$ indicates that normal polarity recorded in this part of the section probably corresponds to chron C23n (either chron C23n.1n or C23n.2n). Considering this interpretation and the age of ca. 61.6 Ma for the top of the Peñas Coloradas Formation, the normal polarity recorded at site LF1207 could be correlated to one of the chron C24 normal subchrons (i.e., C24n.3n, 53.42-53.98 Ma) or to chron C25n (57.10-57.66 Ma). Thus, the base of the Las Flores Formation could be either lower Ypresian (i.e., ca. $54 \mathrm{Ma}$ ) or Thanetian (ca. 57.5 Ma) in age. The sedimentary and stratigraphic data reported here clearly show that a significant erosional unconformity separates the Las Flores Formation from the underlying Peñas Coloradas Formation at the Las Flores locality. Both the age and the regional extent of the basal unconformity over which the Las Flores Formation lies suggest that this surface could have been caused by an erosive event related to a fall in base level. One possible origin of this unconformity could be the effects of global eustatic sea-level fall near the PaleoceneEocene boundary (ca. $56 \mathrm{Ma}$ ), as recorded in other Atlantic basins (e.g., Baum and Vail, 1988; Haq et al., 1988; Miller et al., 2005). Thus, we prefer the correlation of site LF1207 to one of the chron C24 normal subchrons, establishing the age ca. $56 \mathrm{Ma}$ as more probable for the base of the Las Flores Formation. Nevertheless, more data would be necessary to confirm this. The age for the top of this unit at the Las Flores locality is ca. $47 \mathrm{Ma}$, given the $46.714 \pm 0.012 \mathrm{Ma} \mathrm{U}-\mathrm{Pb}$ date constraining the age of the lowest KoluelKaike Formation and the absence of noticeable unconformities in the formational boundary. It is noteworthy that in the coastal area, the top of the unit is likely younger. Given the considerably thicker Las Flores successions and the nondeposition of the Koluel-Kaike Formation along the coast, as well as the lateral relationship between the Las Flores and Koluel-Kaike Formations (e.g., Legarreta et al., 1990; Legarreta and Uliana, 1994; Krause and Piña, 2012; Fig. 2), the Las Flores Formation in its totality probably includes the time of deposition of the Koluel-Kaike Formation.

Although the contact between the Las Flores and Koluel-Kaike Formations often appears transitional in outcrop (Krause et al., 2010; Raigemborn et al., 2010), the ages reported here indicate a temporal separation of $\sim 5$ m.y. between the middle Las Flores Formation (tuff 12CB01) and the lower Koluel-Kaike Formation (sample 12LFKK01). That $5 \mathrm{~m}$.y. of time is distributed across only $25 \mathrm{~m}$ of muddy facies, suggesting that sediment accumulation rates must have been extremely slow in the upper Las Flores Formation and, more likely, that there are condensed sections (i.e., development of paleosols) or hiatuses in this part of the unit. The absence of clear erosive surfaces and the strong contrast in lithology from siliciclastic to pyroclastic facies (also reflected in a significant change in magnetic susceptibility) recorded in the upper Las Flores-lower Koluel-Kaike interval suggest that discontinuities would be nonerosive and probably related to the timing of pedogenesis and changes in sediment supply. Significant time (i.e., $10^{1}-10^{2} \mathrm{k} . \mathrm{y}$.) was consumed during paleosol development within the middle-upper Las Flores Formation (i.e., orange and red beds) and the Koluel-Kaike Formation, where strongly developed, lateritized, paleo-Ultisols and paleoAndisols are arranged in cumulative, composite, and compound sequences (Krause, 2010, 2012; Krause et al., 2010). In particular, the orange and red marker beds are close in time to the $\mathrm{U}-\mathrm{Pb}$ date of $51.403 \pm 0.037 \mathrm{Ma}$ for 12CB01, suggesting a potential link to the early Eocene climatic optimum (see following discussion). The orange and red beds exhibit soil features and thus could be recording a condensed section equivalent to the duration of the early Eocene climate optimum, 2 m.y. (Zachos et al., 2008). Moreover, it seems likely that the top of the paleosols included in this part of the section also mark disconformities.

The new age data presented here are significant for constraining the age of the Las Flores fauna, which is referred to the Itaboraian
SALMA (Bond et al., 1995; Goin et al., 2009; Woodburne et al., 2014a, 2014b). The dated tuff sample 12CB01 $(51.403 \pm 0.037 \mathrm{Ma})$ is located 18-20 m below the Las Flores-Koluel-Kaike contact (Figs. 3, 4B, 5A, 6A, and 8), 5-7 m above a tuff dated to ca. $49.5 \mathrm{Ma}$ by Woodburne et al. (2014b), and 25-27 $\mathrm{m}$ above the beds with the Las Flores fauna (see fig. 3 in Woodburne et al., 2014b). Based on the ${ }^{40} \mathrm{Ar} /{ }^{39} \mathrm{Ar}$ age of ca. 49.5 Ma as the minimum age for the Las Flores fauna, Woodburne et al. (2014b) constrained this fauna to the ca. 53-50 Ma interval. Considering the new, older isotopic age and higher stratigraphic position of our Cerro Blanco tuff, our data indicate that the Las Flores fauna is older than $51.4 \mathrm{Ma}$, thus increasing the minimum age of the fauna by 1.4 m.y. Both the new U-Pb CA-ID-TIMS age presented here and the Woodburne et al. (2014b) ${ }^{40} \mathrm{Ar} /{ }^{39} \mathrm{Ar}$ age are in conflict with the detrital zircon $\mathrm{U}-\mathrm{Pb}$ data presented by Kohn et al. (2015), who concluded that the sandstones bearing the Las Flores fauna could be no older than $47 \pm 1 \mathrm{Ma}$. Our age of the Cerro Blanco tuff (51.403 \pm $0.037 \mathrm{Ma}$ ) shows that the minimum age for the Las Flores fauna is at least $\sim 5$ m.y. older than the ca. 47 Ma maximum age proposed by Kohn et al. (2015). We suspect that the difference between our new U-Pb CA-TIMS age and the detrital U-Pb age of Kohn et al. (2015) could be methodological. Determining precise chronostratigraphic constraints based primarily on LA-ICP-MS dating of detrital zircons is difficult, due to accuracy limitations that can be introduced by postcrystallization Pb-loss as well as possible matrix-introduced analytical biases (Košler et al., 2013). Supported by the new high-resolution geochronologic and magnetostratigraphic results presented here, in addition to the previous ${ }^{40} \mathrm{Ar} /{ }^{39} \mathrm{Ar}$ geochronologic results of Woodburne et al. (2014b), we argue that a $47 \pm 1$ Ma maximum estimate for the Las Flores fauna is inaccurate and too young for this stratigraphic interval and that this fauna is in fact older than ca. 51.4 Ma and younger than ca. $56 \mathrm{Ma}$ (i.e., Ypresian in age; Fig. 8).

\section{Koluel-Kaike Formation (46.7-42.2 Ma)}

Our new high-precision U-Pb CA-ID-TIMS ages for the succession of tuff samples from the base, middle, and upper levels of the KoluelKaike Formation, respectively (Table 1; Fig. 3), in combination with our new magnetostratigraphic data for the entire unit, represent the first direct age constraints for this formation (Figs. 3, $4 \mathrm{E}-4 \mathrm{G}, 5 \mathrm{~B}-5 \mathrm{D}, 6 \mathrm{~B}-6 \mathrm{D}$, and 8 ). The U-Pb date of $46.714 \pm 0.012 \mathrm{Ma}$ from the lower section indicates that the basal beds of the Koluel-Kaike Formation most likely correspond to part of chron C21n (within the age range of 45.72 
47.35 Ma; Fig. 3). The U-Pb date of $44.579 \pm$ $0.013 \mathrm{Ma}$ from the middle section indicates that the reversed polarity zone recorded in the middle of the formation is most likely correlated to chron C20r (43.43-45.72 Ma; Fig. 3). Finally, the date of $42.856 \pm 0.017 \mathrm{Ma}$ indicates that the upper Koluel-Kaike Formation most likely corresponds to chron C20n (42.30-43.43 Ma) and the early part of Chron c19r (41.39-42.30 Ma; Fig. 3). Given our new chronostratigraphic framework for the Las Flores and Koluel-Kaike succession and that of Dunn et al. (2013) for the base of the Gran Barranca Member of the lower Sarmiento Formation, it is now possible to constrain the period of deposition from the upper Las Flores Formation through the Koluel-Kaike Formation to span $\sim 9$ m.y. (Fig. 3).

The new geochronological data provided here show that there is no significant temporal gap between the Koluel-Kaike Formation and the overlying Gran Barranca Member (lower Sarmiento Formation) at the Las Flores and Gran Barranca localities. This confirms stratigraphic-sedimentological observations and interpretations provided in previous contributions (Feruglio, 1949; Bellosi and Madden, 2005; Krause et al., 2010, their fig. 3B; Raigemborn et al., 2010) and differs somewhat from the interpretation of Woodburne et al. (2014a, p. 43 and their fig. 7), who postulated a disconformity of up to $6 \mathrm{~m}$.y. and the erosion of $86 \mathrm{~m}$ of the Vacan Member of the Sarmiento Formation between the Koluel-Kaike Formation and the Gran Barranca Member (lower Sarmiento Formation) at Las Flores (for additional details regarding this difference in interpretation, see also Woodburne et al. [2014b] and Data Repository text [see footnote 1]).

Woodburne et al. (2014b) interpreted the base of the Koluel-Kaike Formation, and thus the Riochican SALMA, to be ca. $49 \mathrm{Ma}$. The new $\mathrm{U}-\mathrm{Pb}$ dates reported here indicate that the Koluel-Kaike Formation is more than 2 m.y. younger than that. If the correlation of the Ernestokokenia faunal zone (= Riochican SALMA) to the Koluel-Kaike Formation were correct, then our data would constrain the age of the Riochican SALMA to lie between 46.7 and 42.2 Ma (Fig. 8). However, it alternatively could be placed anywhere in the time represented by the middle-upper Las Flores Formation because the correlation of the strata preserving the Ernestokokenia faunal zone to the Koluel-Kaike Formation rather than the Las Flores Formation is still uncertain (see earlier discussion in Geologic Setting). Conservatively, this means that the age of the Riochican SALMA can only be estimated broadly to lie somewhere within the time span of ca. 56-42.2 Ma or early-middle Eocene (Ypresian-Lutetian) in age. However, we prefer the more constrained age of 46.742.2 Ma (Lutetian) based on the likelihood, discussed herein, that the upper Las Flores Formation in the coastal area is chronostratigraphically equivalent to the Koluel-Kaike Formation in the Gran Barranca area (Fig. 2). Additional work on these correlations and the stratigraphic relationships of sections bearing fossils characteristic of the Ernestokokenia faunal zone is needed to establish a more accurate stratigraphic and geochronological framework for the Riochican SALMA.

\section{Eocene Faunas, Floras, and \\ Paleoclimate in Patagonia}

The span of time corresponding to the deposition of the Las Flores Formation (?56-47 Ma) includes the time of the floras from Pampa de Jones, Laguna del Hunco, and Río Pichileufú (Fig. 8). The time of deposition for the Las Flores Formation also includes the deposition of the tuff that bears mammals from the Laguna Fría assemblage in North Patagonia, one of the two local faunas recorded near the town of Paso del Sapo, Chubut Province (Tejedor et al., 2009), that were thought to potentially represent a distinct SALMA later informally referred to as the "Sapoan" (e.g., Woodburne et al., 2014a). The mammal-bearing tuff from Laguna Fría immediately overlies an ignimbrite dated to $49.51 \pm 0.32 \mathrm{Ma}$ via ${ }^{40} \mathrm{Ar} /{ }^{39} \mathrm{Ar}$ analysis (Gosses et al., 2006) and underlies a basalt dated via ${ }^{40} \mathrm{Ar} /{ }^{39} \mathrm{Ar}$ to $47.89 \pm 1.21 \mathrm{Ma}$ (AH alkaline basalt; Gosses et al., 2006). These results imply that the Laguna Fría Tuff is coeval with some part of the upper Las Flores Formation, above tuff 12CB01, and below the base of the KoluelKaike Formation (Fig. 8).

The geochronological data provided here also indicate that there is a temporal overlap between the middle-upper Las Flores Formation and the middle-upper section of the La Meseta Formation (Antarctica), particularly with the Cucullaea I Allomember (Fig. 8), which is constrained by means of chemostratigraphic $\left({ }^{87} \mathrm{Sr} /{ }^{86} \mathrm{Sr}\right)$ and magnetostratigraphic data to range in age from 51.6 to $49.0 \mathrm{Ma}$ (Montes et al., 2012, 2013; Montes, personal commun., 2015, to J.M. Krause). The La Meseta Formation bears important mammal assemblages (e.g., Reguero et al., 2013; Gelfo et al., 2015) that have significant affinities to the Paso del Sapo faunas (e.g., Tejedor et al., 2009; Goin et al., 2012).

The geochronological data reported here and by Woodburne et al. (2014b) confirm that the temporal span of the early Eocene climate optimum (ca. 51-53 Ma; Zachos et al., 2008) is represented in the Las Flores Formation, particularly in the middle-upper section (Fig. 3), situ- ating the Las Flores fauna near the time of the early Eocene climate optimum. Peaks of kaolinite reported in the upper Las Flores Formation (Raigemborn et al., 2014), including the orange and reddish marker beds, are compatible with strong chemical weathering and thus consistent with warm and humid climates of the early Eocene climate optimum. Warm and humid environments in the Las Flores Formation are also supported by phytolith and mineralogical data (Raigemborn et al., 2009, 2014) and are consistent with paleoclimatic interpretations from fossil vertebrate studies from the Las Flores fauna (e.g., Pascual and Ortiz-Jaureguizar, 1990; Woodburne et al., 2014a).

Confirmation of temporal continuity without any major gap between the Koluel-Kaike Formation (46.7-42.2 Ma) and the Gran Barranca Member of the Sarmiento Formation (Casamayoran SALMA) at Las Flores-Gran Barranca adds a noteworthy point for discussion regarding the chronostratigraphy in the center of the San Jorge Basin and the ages of the SALMAs recorded there. About $70 \mathrm{~km}$ northeast of Las Flores is Cañadón Vaca, the site where the lowermost section of the Sarmiento Formation within the San Jorge Basin was found (Cañadón Vaca Member of the Sarmiento Formation; Bellosi and Krause, 2014) and the Vacan subage of the Casamayoran SALMA was defined (Cifelli, 1985; Figs. 1B-1C and 2). No outcrops of the Koluel-Kaike Formation are present at this locality, as the Sarmiento Formation lies paraconformably on top of the Las Flores Formation (Bellosi and Krause, 2014, their fig. 3). A precise age has not been determined for the Cañadón Vaca Member in the type locality, although an estimate based on stratigraphic thickness and assumed sedimentary rates places the Cañadón Vaca Member in the ca. 45 Ma to ca. 42 Ma time interval (Bellosi and Krause, 2014). This age estimate is consistent with other estimates, including a ca. 45 Ma estimate based on a fossil xenarthran from correlative strata at Gran Barranca (Carlini et al., 2005). Also, an age of 43 Ma was cited by Strömberg et al. (2013) and Dunn et al. (2015) for the Cañadón Vaca Member of the Sarmiento Formation at Cañadón Vaca. However, in both cases, the analytical and stratigraphic details of these ages have not been published. Given the uniformity of the sedimentological facies characterizing the Gran Barranca Member in the San Jorge Basin, we suggest that the Gran Barranca beds at both Cañadón Vaca and the Gran Barranca type locality correspond to the same depositional time. Considering the well-constrained ages obtained from Gran Barranca localities (e.g., Ré et al., 2010a, 2010b; Dunn et al., 2013), and particularly the maximum age for the Gran Barranca 
Member (42.11 Ma; Dunn et al., 2013), we assume the minimal age for the top of the Cañadón Vaca Member to be ca. $42 \mathrm{Ma}$, as previously interpreted by Bellosi and Krause (2014). Considering the thickness of the Cañadón Vaca Member (55 m; Bellosi and Krause) and the sedimentary rates indicated by those authors, their estimation of ca. $45 \mathrm{Ma}$ for the base of the Cañadón Vaca Member is maintained here.

The estimated age for the Cañadón Vaca Member implies a stratigraphic interpretation in which the deposition of this member at the Cañadón Vaca locality was correlative in time with the upper Koluel-Kaike Formation in the Gran Barranca area. Sediment accumulation of the Cañadón Vaca Member, governed by distal, subaerial fallout of suspended volcanic ash and dust on vegetated plains (tephric loessites) and paleosols related to subhumid conditions (Bellosi and Krause, 2014), agrees with the evidence of climatic deterioration recognized in the upper Koluel-Kaike Formation (e.g., Krause et al., 2010). Furthermore, records of reptiles such as the giant snake Madtsoia (Simpson, 1933b) and Sebecus (Simpson, 1937), in conjunction with the presence of paleo-Alfisols in the lower Cañadón Vaca Member (Bellosi and Krause, 2014), support the lower Cañadón Vaca Member being correlated to the upper Koluel-Kaike Formation and having been deposited under humid/subhumid conditions slightly before the definitive cooling trend associated with the Gran Barranca Member (e.g., Bellosi, 2010; Bellosi and González, 2010; Krause et al., 2010). Both paleoclimatic similarities and geochronological correlation of the Cañadón Vaca Member with the upper Koluel-Kaike Formation also help to explain the high similarity between Vacan taxa and those contained in the "Río Chico Formation" sensu Cifelli (1985) (currently Peñas Coloradas and Las Flores Formations) rather than with those from the Gran Barranca Member of the Sarmiento Formation (Cifelli, 1985).

The span of time elapsed in the upper Las Flores (above tuff sample 12CB01) to KoluelKaike succession encompasses around half of the duration of the long-term cooling trend from the end of the early Eocene climate optimum to the Oi-1 glaciation at ca. $33 \mathrm{Ma}$ (Zachos et al., 2001, 2008). This trend is consistent with local observations in the Koluel-Kaike Formation. Warm and humid conditions are recorded in the lower Koluel-Kaike Formation through paleobotanical (Zucol et al., 2004; Brea et al., 2009), mineralogical, and paleopedologic studies (Raigemborn, 2008; Krause, 2010; Krause et al., 2010; Raigemborn et al., 2014), whereas cooler and drier conditions are recorded in the middle-upper Koluel-Kaike Formation (Krause et al., 2010) and in the coeval Cañadón Vaca
Member (Bellosi and Krause, 2014). Krause et al. (2010) proposed that the early Eocene climate optimum probably was represented in the lower part of the Koluel-Kaike Formation, thus suggesting that the base of this unit could be as old as around $54 \mathrm{Ma}$. The new ages reported here make it clear that the conclusion in Krause et al. (2010) regarding the cooling trend after the early Eocene climate optimum being recorded within the Koluel-Kaike beds is still valid, but the age of the base of the Koluel-Kaike Formation was overestimated by around 7 m.y. in that study.

The span of time corresponding to the deposition of the Koluel-Kaike Formation includes the deposition of the tuffaceous sediments that bear the La Barda mammal assemblage (Tejedor et al., 2009). This La Barda local fauna has a probable age between 47 and $45 \mathrm{Ma}$ (Tejedor et al., 2009) because it overlies a basalt dated via ${ }^{40} \mathrm{Ar} /{ }^{39} \mathrm{Ar}$ at $47.89 \pm 1.21 \mathrm{Ma}$ (Gosses et al., 2006) and underlies andesites that have an estimated age of ca. 43 Ma (Mazzoni et al., 1991). Thus, the deposits bearing the La Barda mammals were deposited at about the same time as the lower-middle Koluel-Kaike Formation, under warm and humid conditions (Tejedor et al., 2009; Krause et al., 2010). Based on the stratigraphic relationships recognized in the field and discussed herein, the upper KoluelKaike Formation would include the time of deposition of the rocks bearing the Vacan fauna, suggesting that the Vacan fauna lived after, and during cooler and drier conditions than, the $\mathrm{La}$ Barda local fauna.

The comparison between chronostratigraphies of early Paleogene beds and associated faunas in Patagonia also raises a noteworthy point regarding the Paso del Sapo fauna (Tejedor et al., 2009) and the "Sapoan" fauna (Woodburne et al., 2014a, 2014b). Tejedor et al. (2009) originally proposed the Laguna Fría (ca. 49.51 Ma) and La Barda (45-47 Ma) local faunas as constituents of a possible new SALMA (later informally referred as the "Sapoan"; Woodburne et al., 2014a, 2014b), temporally younger than the Riochican SALMA and older than the Vacan subage of the Casamayoran SALMA. The relative position of the "Sapoan" between the Riochican and Vacan was later maintained by other authors, albeit with variations in the ranges of estimated numerical ages (Gelfo et al., 2009; Woodburne et al., 2014a, 2014b). Whereas Tejedor et al. (2009) estimated the age of the Paso del Sapo fauna to be between 49.5 and $45 \mathrm{Ma}$, Woodburne et al. (2014b) estimated the age of the "Sapoan" as between 48.5 and $47 \mathrm{Ma}$. The chronostratigraphic and paleoclimatic correlations developed in this study clarify that the two local faunas compos- ing the "Sapoan" (the Laguna Fría and La Barda faunas) likely correspond to two different times and different paleoclimatic conditions. The Laguna Fría assemblage is closer in time and climatic conditions to those of the Las Flores fauna, and the La Barda assemblage is closer in time and climatic conditions to those of the Vacan subage (Fig. 8). This result helps to explain the "dichotomy" that emerged from the faunal analyses of Tejedor et al. (2009) and noted by Woodburne et al. (2014a, p. 43), wherein some "Sapoan" taxa display greater affinity to Itaboraian and Riochican faunas, and other "Sapoan" taxa are more closely associated with the Vacan fauna. In this sense, we consider the "Sapoan" to be an unsuitable biochronological unit because it does not represent a unique interval of time. Rather, it consists of two temporally separate time intervals, each of which overlaps with or is coeval with different, already established SALMA designations.

\section{CONCLUSIONS}

(1) New magnetostratigraphic and geochronological data reported here constrain the temporal span of the middle Las Flores to uppermost Koluel-Kaike succession in the Gran Barranca area to be ca. 51.4-42.2 Ma (mid Ypresian-late Lutetian) in age, with the KoluelKaike Formation being 46.7-42.2 Ma (Lutetian) in age. These new data fill a significant gap in our knowledge of the chronostratigraphy between the Peñas Coloradas Formation (ca. 62.5-61.6 Ma; Clyde et al., 2014) and the Gran Barranca Member of the Sarmiento Formation (ca. 41.738.45 Ma; Dunn et al., 2013) and constrain the Río Chico Group as a whole to span ca. 62.542.2 Ma (latest Danian-late Lutetian) in age.

(2) The chronological framework developed here improves our understanding of the age of the Las Flores fauna (referred to the Itaboraian SALMA) as being older than $51.4 \mathrm{Ma}$ and younger than ca. $56 \mathrm{Ma}$.

(3) Sedimentary and geochronological information from the Las Flores section studied here confirms that no significant unconformity exists at the Koluel-Kaike Formation-Gran Barranca Member (Sarmiento Formation) contact. The absence of any hiatus at the Las Flores and Gran Barranca localities, and the uniformity of the facies in the Gran Barranca Member at both of these localities suggest that the upper KoluelKaike Formation and the Cañadón Vaca Member of the Sarmiento Formation were deposited during a similar span of time.

(4) Comparison of the new chronostratigraphic framework presented here with other important paleontological sites in Patagonia suggests that (a) the time of deposition of the 
Las Flores Formation at Las Flores (which contains a mammal assemblage referred to the Itaboraian SALMA) includes the floras from the La Huitrera Formation (e.g., Laguna del Hunco, Río Pichileufú, and Pampa de Jones), the fauna from the Cucullaea I Allomember (La Meseta Formation), and the Laguna Fría mammal assemblage (oldest "Sapoan"; La Huitrera Formation); and (b) the time of deposition of the upper Koluel-Kaike Formation was contemporaneous with the Vacan (lower Casamayoran SALMA) and the La Barda mammal assemblages.

(5) The proposal of the "Sapoan" as a potentially unique biostratigraphic unit between the Riochican SALMA and the Vacan is rejected because the two component faunas characterizing it as a distinct temporal interval instead are coeval with faunas characteristic of previously recognized SALMAs.

\section{ACKNOWLEDGMENTS}

We thank M. Tejedor (Centro Nacional Patagónico [CENPAT], Argentina) for helpful discussion regarding the "Sapoan" fauna and M. Montes (Instituto Geológico y Minero de España [IGME], Spain) for sharing geochronological information from the La Meseta Formation. Students C. San Martín and M. Juárez (Universidad Nacional de la Patagonia San Juan Bosco) helped during field work. This study was funded by International Association of Sedimentologists Grant Scheme 2006, ANPCyT-PICT 0180 (2010), and International Collaborative Project CONICET-NSF 1040/13 awarded to J.M. Krause. Isotope geochronology analyses were funded by National Science Foundation grants DEB-1556666 and DEB-0919071 to P. Wilf. Logistical support for the field work was provided by the Museo Paleontológico Egidio Feruglio and Pan American Energy LLC (Golfo San Jorge, Argentina). From this company, we particularly thank S. Therisod de Gastón for providing us facility access at Cerro Dragón station.

\section{REFERENCES CITED}

Ameghino, F.G., 1906, Les formations sédimentaires du Crétacé Superieur et du Tertiare de Patagonie avec un paralléle entre leurs faunes mammalogiques et celles de l'ancien continent: Anales del Museo Nacional de Historia Natural de Buenos Aires, v. 15, no. 8, p. 1-568.

Archangelsky, S., 1973, Palinología del Paleoceno de Chubut. I. Descripciones sistemáticas: Ameghiniana, v. 10 , no. 4 , p. $339-399$.

Archangelsky, S., 1976, Palinología del Paleoceno de Chubut. II. Diagramas polínicos: Ameghiniana, v. 13, no. 1 , p. $43-55$.

Archangelsky, S., and Zamaloa, M.C., 1986, Nuevas descripciones palinológicas de las Formaciones Salamanca y Bororó, Paleoceno de Chubut (República Argentina): Ameghiniana, v. 23 , no. $1-2$, p. 35-46.

Baum, G.R., and Vail, P.R., 1988, Sequence stratigraphic concepts applied to Paleogene outcrops, Gulf and Atlantic Basins, in Wilgus, C.K., Hastings, B.S., Kendall, C.G.St.C., Posamentier, H.W., Ross, C.A., and Van Wagoner, J.C., eds., Sea-Level Changes-An Integrated Approach: Society of Economic Paleontologists and Mineralogists (SEPM) Special Publication 42, p. 309-327, doi:10.2110/pec.88.01.0309.

Bellosi, E.S., 2010, Loessic and fluvial sedimentation in Sarmiento Formation pyroclastics, middle Cenozoic of central Patagonia, in Madden, R., Carlini A., Vucetich, M., and Kay, R., eds., The Paleontology of Gran Bar- ranca: Evolution and Environmental Change through the Middle Cenozoic of Patagonia: Cambridge, UK, Cambridge University Press, p. 278-292.

Bellosi, E.S., and González, M.G., 2010, Paleosols of the middle Cenozoic Sarmiento Formation, central Patagonia, in Madden, R., Carlini A., Vucetich, M., and Kay, R., eds., The Paleontology of Gran Barranca: Evolution and Environmental Change through the Middle Cenozoic of Patagonia: Cambridge, UK, Cambridge University Press, p. 293-305.

Bellosi, E.S., and Krause, J.M., 2014, Onset of the middle Eocene global cooling and expansion of open-vegetation habitats in central Patagonia: Andean Geology, v. 41, no. 1, p. 29-48, doi:10.5027/andgeoV41n1-a02.

Bellosi, E.S., and Madden, R.H., 2005, Estratigrafía física preliminar de las secuencias piroclásticas terrestres de la Formación Sarmiento (Eoceno-Mioceno) en la Gran Barranca, Chubut, in 16th Congreso Geológico Argentino, La Plata, Resúmenes, v. 4, p. 427-432.

Berry, E.W., 1937, A Paleocene flora from Patagonia: Johns Hopkins University: Studies in Geology (Tulsa), v. 12, p. 33-50.

Bonaparte, J.F., Van Valen, L.M., and Kramarz, A., 1993, La Fauna Local de Punta Peligro. Paleoceno Inferior de la Provincia de Chubut, Patagonia, Argentina: Evolutionary Monograph 14, $61 \mathrm{p}$

Bond, M., Carlini, A.A., Goin, F.J., Legarreta, L., OrtizJaureguizar, E., Pascual, R., and Uliana, M.A., 1995 Episodes in South American land mammal evolution and sedimentation: Testing their apparent concomitance in a Palaeocene succession from central Patagonia, in Cúneo N.R., ed., 6th Congreso Argentino de Paleontología y Bioestratigrafía Actas: Trelew, Argentina, Museo Paleontológico Egidio Feruglio, p. 47-58.

Bowring, S.A., and Schmitz, M.D., 2003, High-precision $\mathrm{U}-\mathrm{Pb}$ zircon geochronology and the stratigraphic record, in Hanchar, J.M., and Hoskin, P.W.O., eds., Zircon: Mineralogical Society of America and Geochemical Society, Reviews in Mineralogy and Geochemistry 53, p. 305-326, doi:10.2113/0530305.

Brea, M., and Zucol, A.F., 2006, Leños fósiles de Boraginaceae de la Formación Peñas Coloradas (Paleoceno superior), Puerto Visser, Chubut, Argentina: Ameghiniana, v. 43, no. 1 , p. 139-146.

Brea, M., Zucol, A.F., Raigemborn, M.S., and Matheos, S.D., 2004, Leños fósiles del Paleoceno superior (Grupo Río Chico), Provincia del Chubut, Argentina: Ameghiniana, v. 41, no. 4, p. 7R-8R

Brea, M., Matheos, S., Zamuner, A., and Ganuza, D., 2005, Análisis de los anillos de crecimiento del bosque fósil de Victor Szlápelis, Terciario inferior del Chubut, Argentina: Ameghiniana, v. 42, no. 2, p. 407-418.

Brea, M., Matheos, S., Raigemborn, M.S., Iglesias, A., Zucol, A.F., and Prámparo, M., 2007, Aspectos paleoecológicos y paleoambientales del Bosque Petrificado Ameghino (Daniano), Chubut, Argentina, in Díaz-Martínez, E., and Rábano, I., eds., 4th European Meeting on the Palaeontology and Stratigraphy of Latin America: Tres Cantos, Spain: Cuadernos del Museo Geominero, v. 8, p. 45-50.

Brea, M., Zucol, A.F., Raigemborn, M.S., and Matheos, S., 2008, Reconstrucción de paleocomunidades arbóreas mediante análisis fitolíticos en sedimentos del Paleoceno superior-Eoceno? (Formación Las Flores), Chubut, Argentina, in Korstanje, M.A., and Babot, M del P., eds., Matices Interdisciplinarios en Estudios Fitolíticos y de Otros Microfósiles: British Archaeological Reports International Series S1870, p. 91-108.

Brea, M., Bellosi, E., and Krause, M., 2009, Taxaceoxylon katuatenkum n sp. en la Formación Koluel-Kaike (Eoceno inferior-medio), Chubut, Argentina: Un componente de los bosques subtropicales Paleógenos de Patagonia: Ameghiniana, v. 46, no. 1, p. 127-140.

Brea, M., Matheos, S., Raigemborn, M.S., Iglesias, A., Zucol, A., and Prámparo, M., 2011, Paleoecology and paleoenvironments of podocarp trees in the Ameghino Petrified Forest (Golfo San Jorge Basin, Patagonia, Argentina): Constraints for early Paleogene paleoclimate: Geologica Acta, v. 9, no. 1, p. 13-28, doi:10.1344/105 .000001647 .

Carlini, A.A., Ciancio, M., and Scillato-Yané, G.J., 2005, Los Xenarthra de Gran Barranca: Más de 20 Ma de historia, in 16th Congreso Geológico Argentino, La
Plata, Resúmenes: La Plata, Argentina, Asociación Geológica Argentina, v. 1, p. 419-424

Cecil, M.R., Gehrels, G., Ducea, M.N., and Patchett, P.J., 2011, U-Pb-Hf characterization of the central Coast Mountains batholith: Implications for petrogenesis and crustal architecture: Lithosphere, v. 3, no. 4, p. $247-$ 260, doi:10.1130/L134.1.

Cifelli, R., 1985, Biostratigraphy of the Casamayoran, early Eocene of Patagonia: American Museum Novitates, v. 2820 , p. $1-26$.

Clyde, W.C., Wilf, P., Iglesias, I., Slingerland, R.L., Barnum, T., Bijl, P.K., Bralower, T.J., Brinkhuis, H., Comer, E.E., Huber, B.T., Ibañez-Mejia, M., Jicha, B.R., Krause, J.M., Schueth, J.D., Singer, B.S., Raigemborn, M.S. Schmitz, M.D., Sluijs, A., and Zamaloa, M.C., 2014, New age constraints for the Salamanca Formation and lower Río Chico Group in the western San Jorge Basin, Patagonia, Argentina: Implications for CretaceousPaleogene extinction recovery and land mammal age correlations: Geological Society of America Bulletin, v. 126, no. 3-4, p. 289-306, doi:10.1130/B30915.1.

Comer, E.E., Slingerland, R.L., Krause, J.M., Iglesias, A., Clyde, W.C., Raigemborn, M.S., and Wilf, P., 2015, Sedimentary facies and depositional environments of diverse early Paleocene floras, north-central San Jorge Basin, Patagonia, Argentina: Palaios, v. 30, no. 7 p. 553-573, doi:10.2110/palo.2014.064.

Condon, D.J., Schoene, B., McLean, N.M., Bowring, S.A., and Parrish, R.R., 2015, Metrology and traceability of $\mathrm{U}-\mathrm{Pb}$ isotope dilution geochronology (EARTHTIME Tracer Calibration Part I): Geochimica et Cosmochimica Acta, v. 164, p. 464-480, doi:10.1016/j.gca.2015 .05 .026

Davydov, V.I., Crowley, J.L., Schmitz, M.D., and Poletaev, V.I., 2010, High-precision U-Pb zircon age calibration of the global Carboniferous time scale and Milankovitch-band cyclicity in the Donets Basin, eastern Ukraine: Geochemistry, Geophysics, Geosystems, v. 11, Q0AA04, doi:10.1029/2009GC002736.

Dunn, R., Madden, R., Kohn, M., Schmitz, M., Strömberg, C., Carlini, A., Ré, G., and Crowley, J., 2013, A new high precision $\mathrm{U}-\mathrm{Pb}$ chronology for middle Eoceneearly Miocene South American Land Mammal Ages of the Sarmiento Formation, Gran Barranca, Chubut Province, Argentina: Geological Society of America Bulletin, v. 125 , no. 3-4, p. 539-555, doi:10.1130 /B30660.1.

Dunn, R.E., Strömberg, C.A.E., Madden, R.H., Kohn, M.J , and Carlini, A.A., 2015, Linked canopy, climate, and faunal change in the Cenozoic of Patagonia: Science, v. 347 , no. 6219 , p. $258-261$, doi:10.1126/science .1260947

Feruglio, E., 1949, Descripción Geológica de la Patagonia 2: Buenos Aires, Argentina, Dirección General de Yacimientos Petrolíferos Fiscales, Coni Press, 349 p.

Flynn, J.J., and Swisher, C.C., III, 1995, Cenozoic South American land mammal ages: Correlation to global geochronologies, in Berggren, W.A., Kent, D.V., Aubry, M.-P., and Hardenbol, J., eds., Geochronology, Timescales and Global Stratigraphic Correlation: A Unified Framework for an Historical Geology: Society for Sedimentary Geology (SEPM) Special Publication 54, p. 317-333, doi:10.2110/pec.95.04.0317.

Gehrels, G.E., Valencia, V.A., and Ruiz, J., 2008, Enhanced precision, accuracy, efficiency, and spatial resolution of $\mathrm{U}-\mathrm{Pb}$ ages by laser ablation-multicollector-inductively coupled plasma-mass spectrometry: Geochemistry Geophysics Geosystems, v. 9, Q03017, doi:10 .1029/2007GC001805.

Gelfo, J.N., Goin, F.J., Woodburne, M.O., and de Muizon, C., 2009, Biochronological relationships of the earliest South American Paleogene mammalian faunas: Palaeontology, v. 52, no. 1, p. 251-269, doi:10.1111/j .1475-4983.2008.00835.x

Gelfo, J.N., Mörs, T., Lorente, M., López, G.M., and Reguero, M., 2015, The oldest mammals from Antarctica, early Eocene of the La Meseta Formation, Seymour Island: Palaeontology, v. 58, no. 1, p. 101-110, doi:10.1111/pala.12121.

Goin, F.J., Candela, A.M., Abello, M.A., and Oliveira, E.V., 2009, Earliest South American paucituberculatans and their significance in the understanding of "pseudo- 
diprotodont' marsupial radiations: Zoological Journal of the Linnean Society, v. 155 , no. 4, p. 867-884, doi 10.1111/j.1096-3642.2008.00471.x.

Goin, F.J., Tejedor, M.F., Chornogubsky, L., López, G.M., Gelfo, J.N., Bond, M., Woodburne, M.O., Gurovich, Y., and Reguero, M., 2012, Persistence of a Mesozoic, non-therian mammalian lineage (Gondwanatheria) in the mid-Paleogene of Patagonia: Naturwissenschaften, v. 99, no. 6, p. 449-463, doi:10.1007/s00114-012 $-0919-\mathrm{z}$.

Gosses, J., 2006, Stratigraphy and ${ }^{40} \mathrm{Ar} /{ }^{39} \mathrm{Ar}$ Geochronology of the Laguna del Hunco Formation; a Lacustrine and Sub-Aerial Caldera Moat Formation [M.S. thesis] Madison. Wisconsin, University of Wisconsin, $265 \mathrm{p}$.

Gosses, J., Carroll, A., Aragón, E., and Singer, B., 2006, The Laguna del Hunco Formation; lacustrine and subaerial caldera fill, Chubut Province, Argentina: Geological Society of America Abstracts with Programs, v. 38 no. 7 , p. 502 .

Gradstein, F.M., Ogg, J.G., Schmitz, M.D., and Ogg, G.M., eds., 2012, The Geologic Time Scale 2012: Amsterdam, Elsevier B.V., 2 volumes, 1144 p.

Haq, B.U., Hardenbol, J., and Vail, P.R., 1988, Mesozoic and Cenozoic chronostratigraphy and cycles of sealevel changes, in Wilgus, C.K., Hastings, B.S., Kendall, C.G.St.C., Posamentier, H.W., Ross, C.A., an Van Wagoner, J.C., eds., Sea-Level Changes-An Integrated Approach: Society of Economic Paleontologists and Mineralogists (SEPM) Special Publication 42, p. 71-108, doi:10.2110/pec.88.01.0071.

Iglesias, A., Wilf, P., Johnson, K.R., Zamuner, A.B., Cúneo, N.R., Matheos, S.D., and Singer, B.S., 2007, A Paleocene lowland macroflora from Patagonia reveals significantly greater richness than North American analogs: Geology, v. 35 , no. 10, p. 947-950, doi:10 $.1130 / \mathrm{G} 23889 \mathrm{~A} .1$

Jaffey, A.H., Flynn, K.F., Glendenin, L.E., Bentley, W.C., and Essling, A.M., 1971, Precision measurement of half-lives and specific activities of ${ }^{235} \mathrm{U}$ and ${ }^{238} \mathrm{U}$ : Physical Review C: Nuclear Physics, v. 4, no. 5, p. 1889 1906, doi:10.1103/PhysRevC.4.1889.

Kohn, M.J., Strömberg, C.A.E., Madden, R.H., Dunn, R.E., Evans, S., Palacios, A., and Carlini, A.A., 2015, Quasi-static Eocene-Oligocene climate in Patagonia promotes slow faunal evolution and mid-Cenozoic global cooling: Palaeogeography, Palaeoclimatology, Palaeoecology, v. 435, p. 24-37, doi:10.1016/j.palaeo 2015.05.028.

Košler, J., Slama, J., Belousova, E., Corfu, F., Gehrels, G.E., Gerdes, A., Horstwood, M.S.A., Sircombe, K.N., Sylvester, P.J., Tiepolo, M., Whitehouse, M.J. and Woodhead, J.D., 2013, U-Pb detrital zircon analysis-Results of an inter-laboratory comparison: Geostandards and Geoanalytical Research, v. 37, no. 3 p. 243-259, doi:10.1111/j.1751-908X.2013.00245.x.

Krause, J.M., 2010, Paleosuelos e Icnología del Grupo Río Chico (Paleoceno-Eoceno) en la Patagonia Central, Argentina [Ph.D. thesis]: San Luis, Argentina, Universidad Nacional de San Luis, $405 \mathrm{p}$.

Krause, J.M., 2012, Assessment of the relationship vertically stacked paleosols-global paleoclimate. An example from the early Paleogene of Patagonia Argentina, in 34th International Geological Congress Proceedings: Brisbane, Australia, IUGS, p. 3777.

Krause, J.M., and Piña, C.I., 2012, Reptilian coprolites in the Eocene of central Patagonia, Argentina: Journal of Paleontology, v. 86, no. 3, p. 527-538, doi:10.1666/11 -075.1 .

Krause, J.M., Bown, T., Bellosi, E., and Genise, J., 2008, Trace fossils of cicadas in the Cenozoic of central Patagonia, Argentina: Palaeontology, v. 51, no. 2, p. 405418, doi:10.1111/j.1475-4983.2008.00753.x.

Krause, J.M., Bellosi, E.S., and Raigemborn, M.S., 2010 , Lateritized tephric palaeosols from central Patagonia, Argentina: A southern high latitude archive of Palaeogene global greenhouse conditions: Sedimentology, v. 57 , no. 7 , p. 1721-1749, doi:10.1111/j.1365-3091 2010.01161.x.

Kuiper, K.F., Deino, A., Hilgen, F.J., Krijgsman, W., Renne, P.R., and Wijbrans, J.R., 2008, Synchronizing rock clocks of Earth history: Science, v. 320, no. 5875, p. 500-504, doi:10.1126/science.1154339.
Legarreta, L., and Uliana, M.A., 1994, Asociaciones de fósiles y hiatos en el supracretácico-Neógeno de Patagonia: Una perspectiva estratigráfico-secuencial: Ameghiniana, v. 31, no. 3, p. 257-281.

Legarreta, L., Uliana, M.A., and Torres, M.A., 1990, Secuencias deposicionales cenozoicas de Patagonia central: Sus relaciones con las asociaciones de mamíferos terrestres y episodios marinos epicontinentales. Evaluación preliminar, in 2nd Simposio del Terciario de Chile Actas: Concepción, Chile, Universidad de Concepción, p. 135-176.

Lowrie, W., 1990, Identification of ferromagnetic minerals in a rock by coercivity and unblocking temperature properties: Geophysical Research Letters, v. 17, no. 2, p. 159-162, doi:10.1029/GL017i002p00159.

Ludwig, K.R., 2003, User's Manual for Isoplot 3.00: A Geochronology Toolkit for Microsoft Excel: Berkeley Geochronological Center Special Publication 4, 70 p.

Lurcock, P.C., and Wilson, G.S., 2012, PuffinPlot: A versatile, user-friendly program for paleomagnetic analysis: technical brief: Geochemistry Geophysics Geosystems, v. 13, no. 6, Q06Z45, doi:10.1029/2012GC004098.

Madden, R.H., Kay, R.F., and Carlini, A.A., 2010, Gran Barranca: A 23-million-year record of middle Cenozoic faunal evolution in Patagonia, in Madden, $\mathrm{R}$. Carlini A., Vucetich, M., and Kay, R., eds., The Paleontology of Gran Barranca: Evolution and Environmental Change through the Middle Cenozoic of Patagonia: Cambridge, UK, Cambridge University Press, p. 423-439.

Mattinson, J.M., 2005, Zircon U-Pb chemical abrasion ("CA-TIMS") method: Combined annealing and multi-step partial dissolution analysis for improved precision and accuracy of zircon ages: Chemical Geology, v. 220, no. 1-2, p. 47-66, doi:10.1016/j.chemgeo 2005.03.011.

Mazzoni, M.M., Kawashita, K., Harrison, S., and Aragón, E., 1991, Edades radimétricas eocenas, borde occidental del Macizo Norpatagónico: Revista de la Asociación Geológica Argentina, v. 46, no. 1-2, p. 150-158.

McCartney, G.C., 1934, The bentonites and closely related rocks of Patagonia: American Museum Novitates, v. 630 , p. $1-16$.

McLean, N.M., Condon, D.J., Schoene, B., and Bowring, S.A., 2015, Evaluating uncertainties in the calibration of isotopic reference materials and multi-element isotopic tracers (EARTHTIME Tracer Calibration Part II): Geochimica et Cosmochimica Acta, v. 164, p. 481501, doi:10.1016/j.gca.2015.02.040.

Miller, K.G., Kominz, M.A., Browning, J.V., Wright, J.D., Mountain, G.S., Katz, M.E., Sugarman, P.J., Cramer, B.S., Christie-Blick, N., and Pekar, S.F., 2005, The Phanerozoic record of global sea-level change: Science, v. 310, p. 1293-1298, doi:10.1126/science .1116412

Montes, M., Santillana, S., Nozal, F., Beamud, E., and Marenssi, S., 2012, Estratigrafía del Paleoceno medioEoceno de la Antártida, Grupo Seymour, Isla Marambio (Seymour), Mar de Weddell, in 8th Congreso Geológico Español, Oviedo, España: Geo-Temas, v. 13, p. 108.

Montes, M., Nozal, F., Santillana, S., Marenssi, S., and Olivero, E., 2013, Mapa Geológico de la Isla Marambio (Seymour): Madrid, Spain, Instituto Geológico y Minero de España-Instituto Antártico Argentino, Serie Cartográfica Geocientífica Antártica, scale 1:20,000.

Ortiz-Jaureguizar, E., and Cladera, G.A., 2006, Paleoenvironmental evolution of southern South America during the Cenozoic: Journal of Arid Environments, v. 66, no. 3, p. 498-532, doi:10.1016/j.jaridenv.2006.01.007.

Pascual, R., and Ortiz-Jaureguizar, E., 1990, Evolving climates and mammal faunas in Cenozoic South America: Journal of Human Evolution, v. 19, no. 1-2, p. 23-60, doi:10.1016/0047-2484(90)90011-Y.

Petriella, B., and Archangelsky, S., 1975, Vegetación y ambiente en el Paleoceno de Chubut, in 1st Congreso Argentino de Paleontología y Bioestratigrafía Actas: Tucumán, Argentina, Universidad Nacional de Tucumán-Fundación Miguel Lillo, v. 2, p. 257-270.

Raigemborn, M.S., 2008, Estudio Estratigráfico, Sedimentológico y Composicional de las Sedimentitas del Terciario Inferior (Grupo Río Chico) en el Sector Sud- oriental del Chubut Extraandino [Ph.D. thesis]: La Plata, Argentina, Universidad Nacional de La Plata, $352 \mathrm{p}$

Raigemborn, M.S., Brea, M., Zucol, A., and Matheos, S., 2009, Early Paleogene climate at mid latitude in South America: Mineralogical and paleobotanical proxies from continental sequences in Golfo San Jorge Basin (Patagonia, Argentina): Geologica Acta, v. 7, no. 1-2, p. 125-148, doi:10.1344/105.000000269.

Raigemborn, M.S., Krause, J.M., Bellosi, E.S., and Matheos, S., 2010, Redefinición estratigráfica del Grupo Río Chico (Paleógeno inferior), en el norte de la cuenca del Golfo San Jorge, Chubut, Argentina: Revista de la Asociación Geológica Argentina, v. 67, no. 2, p. 239-256.

Raigemborn, M.S., Gómez-Peral, L.E., Krause, J.M., and Matheos, S.D., 2014, Controls on clay minerals assemblages in an early Paleogene nonmarine succession: Implications for the volcanic and paleoclimatic record of extra-Andean Patagonia, Argentina: Journal of South American Earth Sciences, v. 52, p. 1-23, doi: 10.1016/j.jsames.2014.02.001.

Ré, G., Bellosi, E.S., Heizler, M., Vilas, J., Madden, R., Carlini, A., Kay, R., and Vucetich, M.G., 2010a, Geochronology for the Sarmiento Formation at Gran Barranca, in Madden, R., Carlini A., Vucetich, M., and Kay, R., eds., The Paleontology of Gran Barranca: Evolution and Environmental Change through the Middle Cenozoic of Patagonia: Cambridge, UK, Cambridge University Press, p. 46-59.

Ré, G.H., Geuna, S.E., and Vilas, J.F., 2010b, Paleomagnetism and magnetostratigraphy of Sarmiento Formation (Eocene-Miocene) at Gran Barranca, Chubut, Argentina, in Madden, R., Carlini A., Vucetich, M., and Kay, R., eds., The Paleontology of Gran Barranca: Evolution and Environmental Change through the Middle Cenozoic of Patagonia: Cambridge, UK, Cambridge University Press, p. 32-45.

Reguero, M., Goin, F., Acosta Hospitaleche, C., Dutra, T. and Marenssi, S., 2013, Late Cretaceous/Paleogene West Antarctica Terrestrial Biota and its Intercontinental Affinities: London, Springer, Briefs in Earth System Sciences, South America and the Southern Hemisphere, 120 p., doi:10.1007/978-94-007-5491-1.

Romero, E.J., 1968, Palmoxylon patagonicum n. sp. del Terciario Inferior de la Provincia de Chubut, Argentina: Ameghiniana, v. 5, no. 10, p. 417-432.

Schmitz, M.D., and Davydov, V.I., 2012, Quantitative radiometric and biostratigraphic calibration of the Pennsylvanian-Early Permian (Cisuralian) time scale and pan-Euramerican chronostratigraphic correlation: Geological Society of America Bulletin, v. 124, no. 3-4, p. 549-577, doi:10.1130/B30385.1

Schmitz, M.D., and Schoene, B., 2007, Derivation of isotope ratios, errors and error correlations for $\mathrm{U}-\mathrm{Pb}$ geochronology using ${ }^{205} \mathrm{~Pb}-{ }^{235} \mathrm{U}-\left({ }^{233} \mathrm{U}\right)$-spiked isotope dilution thermal ionization mass spectrometric data: Geochemistry Geophysics Geosystems, v. 8, no. 8, Q08006, doi:10.1029/2006GC001492.

Selkin, P.A., Strömberg, C.A.E., Dunn, R., Kohn, M.J., Carlini, A.A., Davies-Vollum, K.S., and Madden, R.H., 2015, Climate, dust, and fire across the EoceneOligocene transition, Patagonia: Geology, v. 43, no. 7 , p. 567-570, doi:10.1130/G36664.1

Simpson, G.G., 1933a, Stratigraphic nomenclature of the Early Tertiary of central Patagonia: American Museum Novitates, v. 644, p. 1-13.

Simpson, G.G., 1933b, A new fossil snake from the Notostylops beds of Patagonia: Bulletin of the American Museum of Natural History, v. 67, p. 1-22.

Simpson, G.G., 1935a, Descriptions of the oldest known South American mammals from the Río Chico formation: American Museum Novitates, v. 793, p. 1-25.

Simpson, G.G., 1935b, Occurrence and relationships of the Río Chico fauna of Patagonia: American Museum Novitates, v. 818, p. 1-21.

Simpson, G.G., 1937, New reptiles from the Eocene of South America: American Museum Novitates, v. 927. p. $1-3$

Simpson, G.G., 1948, The Beginning of the Age of Mammals in South America: Bulletin of the American $\mathrm{Mu}-$ seum of Natural History 91, p. 1-232.

Stacey, J.S., and Kramers, J.D., 1975, Approximation of terrestrial lead isotope evolution by a two-stage model: 
Earth and Planetary Science Letters, v. 26, no. 2, p. 207-221, doi:10.1016/0012-821X(75)90088-6.

Strömberg, C.E., Dunn, R.E., Madden, R.H., Kohn, M.J., and Carlini, A.A., 2013, Decoupling the spread of grasslands from the evolution of grazer-type herbivores in South America: Nature Communications, v. 4, no. 1478 , doi: $10.1038 /$ ncomms 2508 .

Tauxe, L., Banerjee, S.K., Butler, R.F., and van der Voo, R. 2016, Essentials of Paleomagnetism (4th Web ed.): https://earthref.org/MagIC/books/Tauxe/Essentials/ (last accessed May 24 2016).

Tejedor, M.F., Goin, F.J., Gelfo, J.N., López, G.M., Bond, M., Carlini, A.A., Scillato-Yané, G.J., Woodburne, M.O., Chornogubsky, L., Aragón, E., Reguero, M.A., Czaplewski, N.J., Vincon, S., Martin, G.M., and Ciancio, M.R., 2009, New early Eocene mammalian fauna from western Patagonia, Argentina: American Museum Novitates, v. 3638, p. 1-43, doi:10.1206/577.1.

Ting, S.Y., Tong, Y.S., Clyde, W.C., Koch, P.L., Meng, J., Wang, Y.Q., Bowen, G.J., Li, Q., and Snell, K.E., 2011, Asian early Paleogene chronology and mammalian faunal turnover events: Vertebrata PalAsiatica, v. 49, p. 1-28.

Vandenberghe, N., Hilgen, F.J., Speijer, R.P., Ogg, J.G., Gradstein, F.M., Hammer, O., Hollis, C.J., and Hooker, J.J., 2012, The Paleogene Period, in Gradstein, F.M Ogg, J.G., Schmitz, M.D., and Ogg, G.M., eds., The Geologic Time Scale 2012: Amsterdam, Elsevier B.V., Volume 2, p. 855-921, doi:10.1016/B978-0-444 $-59425-9.00028-7$

Wack, M., 2010, A new software for the measurement of magnetic moments using SQUID and spinner magnetometers: Computers \& Geosciences, v. 36, no. 9, p. 1178-1184, doi:10.1016/j.cageo.2010.05.002.

Watson, G.S., 1956, A test for randomness of directions: Geophysical Supplements to Monthly Notices of the Royal Astronomical Society, v. 7, no. 4, p. 160-161, doi:10.1111/j.1365-246X.1956.tb05561.x.
Wilf, P., 2012, Rainforest conifers of Eocene Patagonia: Attached cones and foliage of the extant Southeast Asian and Australasian genus Dacrycarpus (Podocarpaceae) American Journal of Botany, v. 99, no. 3, p. 562-584, doi:10.3732/ajb.1100367.

Wilf, P., Cúneo, N.R., Johnson, K.J., Hicks, J.F., Wing, S.L., and Obradovich, J.D., 2003, High plant diversity in Eocene South America: Evidence from Patagonia: Science, v. 300 , no. 5616 , p. $122-125$, doi: 10.1126 /science. 1080475.

Wilf, P., Johnson, K.R., Cúneo, N.R., Smith, M.E., Singer, B.S., and Gandolfo, M.A., 2005, Eocene plant diversity at Laguna del Hunco and Río Pichileufú, Patagonia, Argentina: American Naturalist, v. 165, no. 6, p. 634-650, doi:10.1086/430055.

Wilf, P., Singer, B.S., Zamaloa, M.C., Johnson, K.R., and Cúneo, R., 2010, Early Eocene ${ }^{40} \mathrm{Ar} /{ }^{39} \mathrm{Ar}$ age for the Pampa de Jones plant, frog, and insect biota (Huitrera Formation, Neuquén Province, Patagonia, Argentina): Ameghiniana, v. 47 , no. 2, p. 207-216, doi:10.5710 /AMGH.v47i2.7.

Woodburne, M.O., ed., 2004, Late Cretaceous and Cenozoic Mammals of North America: Biostratigraphy and Geochronology: New York, Columbia University Press, 376 p., doi:10.7312/wood 13040.

Woodburne, M.O., Goin, F.J., Bond, M., Carlini, A.A. Gelfo, J.N., López, G.M., Iglesias, A., and Zimicz, A.N., 2014a, Paleogene land mammal faunas of South America; a response to global climatic changes and indigenous floral diversity: Journal of Mammalian Evolution, v. 21, no. 1, p. 1-73, doi:10.1007/s 10914 $-012-9222-1$.

Woodburne, M.O., Goin, F.J., Raigemborn, M.S., Heizler, M., Gelfo, J.N., and Oliveira, E.V., 2014b, Revised timing of the South American early Paleogene land mammal ages: Journal of South American Earth Sciences, v. 54, p. 109-119, doi:10.1016/j.jsames.2014 .05 .003 .
Zachos, J.C., Pagani, M., Sloan, L., Thomas, E., and Billups, K., 2001, Trends, rhythms, and aberrations in globa climate $65 \mathrm{Ma}$ to present: Science, v. 292 , no. 5517 , p. 686-693, doi:10.1126/science.1059412.

Zachos, J.C., Dickens, G.R., and Zeebe, R.E., 2008, An early Cenozoic perspective on greenhouse warming and carbon-cycle dynamics: Nature, v. 451, p. 279-283, doi: 10.1038/nature06588.

Zamaloa, M.C., and Andreis, R.R., 1995, Asociación palinológica del Paleoceno temprano (Formación Salamanca) en Ea. Laguna Manantiales, Santa Cruz, Argentina, in Cúneo, N.R., ed., 6th Congreso Argentino de Paleontología y Bioestratigrafía Actas: Trelew, Argentina, Museo Paleontológico Egidio Feruglio, p. 301-305.

Zucol, A.F., Brea, M., Raigemborn, M.S., and Matheos, S., 2004, Asociación fitolítica en las formaciones Las Flores, Koluél Kaike y Sarmiento en Gran Barranca, lago Colhué Huapi (Chubut, Argentina): Ameghiniana, v. 41 , no. 4 R, p. $25 \mathrm{R}-26 \mathrm{R}$.

Zucol, A., Brea, M., and Bellosi, E., 2010, Phytolith analysis in Gran Barranca (central Patagonia): The middle-late Eocene, in Madden, R., Carlini, A., Vucetich, M., and Kay, R., eds., The Paleontology of Gran Barranca: Evolution and Environmental Change through the Middle Cenozoic of Patagonia: Cambridge, UK, Cambridge University Press, p. 317-340.

Science Editor: Bradley S. Singer

Associate Editor: Troy Rasbury

Manuscript Received 27 ApriL 2016

Revised Manuscript Received 28 September 2016

ManUSCRIPT ACCEPTED 10 JanUARY 2017

Printed in the USA 